\title{
Stable isotopes and trace elements as indicators of diet and habitat use in cetaceans: predicting errors related to preservation, lipid extraction, and lipid normalization
}

\author{
Véronique Lesage $^{1, *}$, Yves Morin ${ }^{1}$, Ève Rioux ${ }^{1,2}$, Corinne Pomerleau $^{1,2}$, \\ Steven H. Ferguson ${ }^{3}$, Émilien Pelletier ${ }^{2}$ \\ ${ }^{1}$ Maurice Lamontagne Institute, Fisheries and Oceans Canada, Mont-Joli, Québec G5H 3Z4, Canada \\ ${ }^{2}$ Institut des Sciences de la Mer, Université du Québec à Rimouski, Rimouski, Québec G5L 3A1, Canada \\ ${ }^{3}$ Freshwater Institute, Fisheries and Oceans Canada, Winnipeg, Manitoba R3T 2N6, Canada
}

\begin{abstract}
Accurately predicting errors related to preservation, lipid extraction, and lipid normalization on chemical tracers would enable the use of archived samples in long-term studies of trophic ecology and habitat use of aquatic species. We determined whether stable carbon and nitrogen isotope ratios and concentrations of 14 trace elements can be accurately predicted from dimethyl sulfoxide (DMSO)-preserved mammal skin, which would provide equivalent estimates to that from unpreserved tissue. We tested 3 lipid-correction approaches for applicability to cetacean skin, a largely unexplored taxon and tissue, and provide a model for evaluating impacts of errors from lipid extraction or normalization on diet composition estimated using isotopic mixing models. DMSO had unpredictable effects on trace element concentrations, rendering DMSO-preserved samples inefficient for retrospective studies. However, lipid extraction and DMSO preservation resulted in predictable and similar, although not identical, effects on isotopic signatures across 4 cetacean species with different skin structure and thickness, making correction for these effects a potentially viable alternative to lipid and DMSO extraction. Generally, lipid-normalization models were reliable when applied to cetacean skin, as errors were similar to those from other species or tissues. Because model fit generally improved with data specificity, developing tissue- and species-specific parameters and equations is probably more important than model choice, although the mass-balance model was considered the most robust across aquatic vertebrates and tissues. The effects of errors associated with the various treatments and lipid normalization on isotopic mixing results increased as the isotopic distance among prey sources decreased, suggesting that empirical corrections as an alternative to $\delta^{13} \mathrm{C}$ determination from lipid-extracted duplicate samples need to be evaluated a priori relative to study objectives and anticipated results.
\end{abstract}

KEY WORDS: Stable isotopes · Lipids · Trace elements · Preservation · Aquatic species Marine mammals $\cdot$ Cetaceans $\cdot$ DMSO

Resale or republication not permitted without written consent of the publisher

\section{INTRODUCTION}

The geochemical characteristics of aquatic ecosystems are influenced regionally by a number of factors, including land proximity, atmospheric circulation, water mass physico-chemical characteristics, geology, degree of urbanization, and agricultural development (Brown 1976, Goericke \& Fry 1994, Painter et al. 1994, Vitousek et al. 1997, Fry 2006). Geochemical characteristics are reflected to some extent in tissues of biological components of ecosystems and may be amplified through the food chain (Outridge et al. 1997, 
Atwell et al. 1998, Hobson et al. 2002). As a result, chemical tracers such as naturally occurring carbon (C) and nitrogen $(\mathrm{N})$ stable isotopes, or trace elements are increasingly used in ecological studies to examine trophic relationships, habitat use, and migratory patterns of wildlife species (e.g. Das et al. 2003, Bustamante et al. 2006, Crawford et al. 2008). Long-term changes in these tracers are of particular interest in the context of global warming and for monitoring trends in the structure and productivity of ecosystems (e.g. Schell 2000, Smetacek \& Nicol 2005). As a result, there has been a growing interest in using archived material, which raises the issue of preservation adequacy (e.g. Renaud et al. 1995, Barrow et al. 2008). Preservation techniques vary depending on initial intent for tissue archival, and generally include immersion in formalin and/or ethanol, or immersion in dimethyl sulfoxide (DMSO) saturated with $\mathrm{NaCl}$, as well as freezing. Accurately predicting effects of solvents on chemical tracers would allow for the use of archived samples in long-term studies of trophic ecology and habitat use of aquatic species.

Studies using isotopes or trace elements with animals from lower taxa generally rely on the analysis of the whole body or internal organs (e.g. muscle, liver, etc.) of dead specimens. In the field of cetacean research, where captures are often unrealistic, remote biopsy sampling of skin (and underlying fat or blubber) represents a common technique for obtaining information on trophic ecology, reproductive status, stock identity, or contamination of individuals (e.g. Borobia et al. 1995, Parsons et al. 2003, Krahn et al. 2007, Amaral 2010). Although the recommendation is for low-temperature cryogenic preservation (Sweeting et al. 2004, Budge et al. 2006), possibilities for retrospective ecological studies of marine mammals, and particularly cetaceans, commonly arise from DMSOpreserved tissue banks collected for the purpose of genetic analyses. However, biases in $\mathrm{C}$ and $\mathrm{N}$ isotope ratios or trace element concentrations associated with DMSO preservation are not fully understood (Hobson et al. 1997, Todd et al. 1997, Wanek et al. 2001, Barrow et al. 2008).

Over the last $5 \mathrm{yr}$, there has also been a growing concern that methods traditionally used for preparing samples for stable isotope analyses may incorporate significant bias. The ${ }^{13} \mathrm{C}$ depletion of lipids relative to protein (DeNiro \& Epstein 1977, McConnaughey \& McRoy 1979) and biases they may cause to our interpretation of trophic ecology (e.g. Kiljunen et al. 2006, Murry et al. 2006) led to a growing consensus about the need to extract lipids or account for their effects (Post et al. 2007). Until recently, lipid extraction prior to isotope analyses was the accepted approach. This procedure was based on the untested assumption that an absence of nitrogenous components in chemical solvents used for lipid extraction would not significantly alter $\delta^{15} \mathrm{~N}$ values of tissue. However, recent studies on a variety of freshwater or marine invertebrates and vertebrates documented an enrichment in $\delta^{15} \mathrm{~N}$ as a result of lipid extraction (e.g. Pinnegar \& Polunin 1999, Sotiropoulos et al. 2004, Murry et al. 2006, Sweeting et al. 2006, Mintenbeck et al. 2008), although other studies documented negative or no effects of lipid extraction on $\delta^{15} \mathrm{~N}$ values (Bodin et al. 2007, Ricca et al. 2007, Barrow et al. 2008, Logan \& Lutcavage 2008). The variability observed in the degree of $\mathrm{N}$ enrichment indicated the need to evaluate solvent effects on various tissues and species (Sotiropoulos et al. 2004). As an alternative to lipid extraction, some authors have proposed models for lipid normalization of $\delta^{13} \mathrm{C}$ values (McConnaughey \& McRoy 1979, Alexander et al. 1996, Fry et al. 2003). However, their applicability across taxa and tissues has been questioned, and alternative models have been proposed in some cases (e.g. Satterfield \& Finney 2002, Kiljunen et al. 2006, Sweeting et al. 2006, Bodin et al. 2007, Post et al. 2007, Smyntek et al. 2007, Mintenbeck et al. 2008, Logan et al. 2008), although none were developed in the perspective of use with marine mammals or skin tissue. Errors introduced by lipids or models to account for them may bias interpretations of trophic ecology of species, especially when isotopic sources are not far apart (Post et al. 2007).

Here, we determine whether stable $\mathrm{C}$ and $\mathrm{N}$ isotope ratios and concentrations of 14 trace elements can be accurately predicted and restored from DMSOpreserved samples so as to provide equivalent estimates as from unpreserved tissue. Lipid-normalization approaches currently proposed for muscle or whole body of other aquatic taxa in place of lipid extraction are tested for their applicability to a tissue and taxon that have been largely unexplored, the skin of cetaceans. Errors introduced by correcting for effects of DMSO and lipid extraction are modeled for their impacts on diet estimates issued from isotopic mixing models (Phillips \& Gregg 2003, Semmens et al. 2009, Parnell et al. 2010). Members of the 2 sub-orders of cetaceans, Odontoceti (beluga and harbor porpoises) and Mysticeti (bowhead whales and 3 species of Balaenopteridae), are examined to contrast results among species with different skin structure and thickness (Sokolov 1982).

\section{MATERIALS AND METHODS}

Data collection and sample preparation. Skin samples $(n=127)$ were obtained from 6 species of 4 families of odontocete or mysticete, including the Mon- 
odontidae ( $\mathrm{n}=46$ beluga whales Delphinapterus leucas), Phocoenidae ( $\mathrm{n}=20$ harbor porpoises Phocoena phocoena), Balaenopteridae ( $\mathrm{n}=24$, including 19 minke whales Balaenoptera acutorostrata, 4 finback whales Balaenoptera physalus, and 1 humpback whale Megaptera novaeangliae), and Balaenidae ( $\mathrm{n}=37$ bowhead whales Balaena mysticetus). A block of tissue $(10 \times 10 \mathrm{~cm})$ consisting of skin, full blubber depth, and underlying muscle was collected post mortem from well-preserved to moderately decomposed specimens (codes $\leq 3$, Geraci \& Lounsbury 1993) found stranded (beluga, minke, finback, and humpback whales) or bycaught in gillnet fisheries (harbor porpoises) in the Gulf of St. Lawrence, Canada. Samples from stranded specimens were taken from the side of the animal unexposed to the sun to ensure maximum freshness. Skin tissue ( 0.25 g wet weight) was also collected from free-ranging bowhead whales through remote biopsy sampling, and stored in cryovials. Tissues from dead whales were wrapped into aluminum foil and placed in air-tight plastic bags. All samples were stored at $-20^{\circ} \mathrm{C}$ until analyses.

The pigmented skin (i.e. the epidermis) was excised from dermis and hypodermis (subcutaneous fat layer) using a sterile hexane-rinsed scalpel while samples were still frozen. Each sample was split into 2 pieces and stored in clean borosilicate glass scintillation vials (with white urea caps and cork foil liner). Half of the sample was returned immediately to the freezer, whereas the second half was immersed in a DMSO solution (20\% vol.) of deionized water saturated with $\mathrm{NaCl}$ and stored at $4^{\circ} \mathrm{C}$ for $1 \mathrm{yr}$. All samples were placed in aluminum cups, freeze-dried to a constant mass, and ground to a powder (Wig-L-Bug, Crescent Dental Mfg.). Freeze-drying was preceded by a 3wash rinse using deionized water in the case of DMSO-preserved samples; no rinsing was performed for frozen samples.

Except for bowhead whale biopsies, which were used in 1 test only given their small size, samples stored in DMSO or kept frozen were split into 2 pieces of $\sim 2 \mathrm{~g}$ each. One set of subsamples (i.e. 1 frozen and 1 DMSO-preserved) received no further treatment prior to isotope and trace-element analyses to test for effects of the preservative (DMSO). A second set of subsamples from the 3 species group and the bowhead whale biopsies were lipid-extracted to evaluate effects of this procedure on frozen and DMSO-preserved samples. Two subsamples of DMSO-preserved beluga tissue were used to assess the efficacy of a 3-wash rinsing versus a $24 \mathrm{~h}$ soak in deionized water for the partial elimination of DMSO prior to lipid extraction.

Lipid extraction was conducted using $\sim 0.2 \mathrm{~g}$ of dried material and a solvent consisting of a mixture of chloroform and methanol (2:1 v/v). Skin tissue was placed in a glass tube with $10 \mathrm{ml}$ of the solvent mixture, sonicated for $10 \mathrm{~min}$, and stored overnight at $4^{\circ} \mathrm{C}$ with gentle shaking. The sample was centrifuged for $10 \mathrm{~min}$ and supernatant removed (Folch et al. 1957). The extraction procedure was repeated 3 times, after which a test for complete extraction was performed using sulfophosphovanillin (Barnes \& Blackstock 1973). Following lipid removal, samples were dried by evaporation, rinsed with distilled water, dried overnight at $50^{\circ} \mathrm{C}$, and powdered again.

Chemical analysis. Stable-isotope analysis: Samples were analyzed for stable $\mathrm{C}$ and $\mathrm{N}$ isotope ratios using a continuous-flow stable-isotope mass spectrometer coupled to a Carlo Erba elemental analyzer (CHNS-O EA1108) (Environmental Isotope Laboratory, University of Waterloo, Canada). Isotope ratios are expressed in delta $(\delta)$ notation as parts per thousand (or per mil, \%o) differences from a standard $\left(R_{\text {standard }}\right)$, i.e. carbonates from Vienna Pee Dee Belemnite (PDB) limestone (using the Vienna PDB scale) for $\delta^{13} \mathrm{C}$ and atmospheric $\mathrm{N}$ for $\delta^{15} \mathrm{~N}$, following:

$$
\delta X=\left[\left(R_{\text {sample }} / R_{\text {standard }}\right)-1\right] \times 1000
$$

where $X$ is ${ }^{13} \mathrm{C}$ or ${ }^{15} \mathrm{~N}$ and $R$ is the corresponding ${ }^{13} \mathrm{C} /{ }^{12} \mathrm{C}$ or ${ }^{15} \mathrm{~N} /{ }^{14} \mathrm{~N}$ ratio. Analytical error based on replicate analyses of samples $(\mathrm{n}=54)$ and laboratory standards was $0.1 \%$ for both $\delta^{13} \mathrm{C}$ and $\delta^{15} \mathrm{~N}$. Values for $\mathrm{C}: \mathrm{N}$ ratios are reported based on uncorrected percentage element data.

Trace element concentrations: Freeze-dried homogenized samples ( 0.05 g) were accurately weighed, and digested in $1 \mathrm{ml}$ of high-purity concentrated $\mathrm{HNO}_{3}$ and $0.5 \mathrm{ml}$ of $\mathrm{H}_{2} \mathrm{O}_{2}(30 \% \mathrm{v} / \mathrm{v})$ at $65^{\circ} \mathrm{C}$ for $2 \mathrm{~h}$. The mineralized samples were diluted to $50 \mathrm{ml}$ with nanopure water. An autosampler (ASX-510 Autosampler Agilent 1100 Series) was used to introduce samples into the inductively coupled plasma ionizer linked to a mass spectrometer (ICP-MS, Octopole Reaction System Agilent 7500c) for analysis of 14 elements (beryllium [Be], vanadium $[\mathrm{V}]$, chromium [Cr], manganese [Mn], iron $[\mathrm{Fe}]$, cobalt [Co], nickel [Ni], copper $[\mathrm{Cu}]$, zinc $[\mathrm{Zn}]$, arsenic [As], selenium [Se], cadmium [Cd], barium $[\mathrm{Ba}]$, and lead $[\mathrm{Pb}])$. Multielement Standard Solution IV, in which $\mathrm{HNO}_{3} 10 \%$ was added to $50 \mathrm{ml}$ of nanopure water, was used to prepare 7 standard solutions and develop calibration curves.

Possible contamination during the analytical process was assessed through the analysis of blank samples, consisting of a solution of $9 \mathrm{ml}$ of nanopure water and $1 \mathrm{ml}$ of $10 \% \mathrm{HNO}_{3}$. Precision and accuracy of the method were assessed using certified reference material (dogfish liver DOLT-2, National Research Council of Canada). Procedural blanks and standards were distributed among whale sample batches and submitted to the same digestion and analytical procedure as skin 
samples. Analyses were done in triplicate for each sample and coefficients of variation were $<5 \%$ in all cases. Concentrations of trace elements are expressed on a dry-weight (dry wt) basis. Element-specific detection limits were given by samples of low value and/or blank samples and were <0.01 ( $\mathrm{Co}, \mathrm{As}, \mathrm{Mn}, \mathrm{Pb}$, $\mathrm{Be}, \mathrm{Cd}, \mathrm{Ba}, \mathrm{V}), 0.03$ (Ni, Cr), 0.07 (Cu, Zn), $0.6(\mathrm{Fe})$, and 0.1 (Se) $\mu g^{-1}$ dry wt.

Data treatment. Lipid normalization of $C$ isotopic signatures: Four lipid-normalization models for C isotope ratios were tested using data from all species groups except bowhead whales. The first model, developed by McConnaughey \& McRoy (M\&M) (McConnaughey \& McRoy 1979; see also McConnaughey 1978) for the whole body of various marine vertebrates and invertebrates, including marine birds and mammals, requires information about 3 parameters: lipid content $L$, the proportions of $\mathrm{C}$ and $\mathrm{N}$ in the untreated sample (C:N), and the isotopic difference (in \%o) between pure lipid and pure protein $D$. This model is based on the following equations:

$$
\begin{gathered}
L=\frac{93}{1+[0.246 \times(\mathrm{C}: \mathrm{N})-0.775]^{-1}} \\
\delta^{13} \mathrm{C}^{\prime}=\delta^{13} \mathrm{C}+D \times\left(I+\frac{3.90}{1+287 / L}\right)
\end{gathered}
$$

where $\delta^{13} \mathrm{C}$ and $\delta^{13} \mathrm{C}^{\prime}$ are the measured and lipidnormalized values of the sample, respectively, $D$ defines the slope of the curve, and $I$ is a constant. The M\&M model assumed a $D$ of $6 \%$ and an $I$ of -0.207 (McConnaughey 1978), using a 'strong theoretical background based on biological rationale' (Kiljunen et al. 2006). Kiljunen et al. (2006) re-estimated $D$ and $I$ and concluded that the best fit for their freshwater, estuarine, and marine fish muscle data was obtained with $D=7.018 \%$ and $I=0.048$. In the present study, the parameters $D$ and $I$ were re-estimated by iteratively fitting the original equations of the M\&M model (Eqs. 1 \& 2) to our observed data, i.e. $\delta^{13} \mathrm{C}$ of lipid-extracted and untreated samples, and C:N of untreated samples, using the least-squares procedures available in $\mathrm{R}(\mathrm{R}$ Development Core Team 2009). This was done assuming that Eq. (2), which was determined to be valid for muscle tissue of marine fish (Kiljunen et al. 2006) and whole body of a variety of marine species (McConnaughey \& McRoy 1979), was also valid for cetacean skin. The model was re-estimated using $D$ and $I$ from the original model and those obtained by Kiljunen et al. (2006) as initial values. Iterations were stopped when convergence reached $1.0 \times 10^{-8}$. Model performance was assessed using model efficiency $(\mathrm{EF})$, an estimate of model fit which is more appropriate for the class of non-linear regressions than the coefficient of determination $\mathrm{R}^{2}$, and which is calculated as follows:

$$
\mathrm{EF}=1-\frac{\sum\left(y_{i}-\hat{y}_{i}\right)^{2}}{\sum\left(y_{i}-\bar{y}_{i}\right)^{2}}
$$

where $y_{i}$ is the observed and $\hat{y}_{i}$ the predicted value of the difference between $\delta^{13} \mathrm{C}$ and $\delta^{13} \mathrm{C}^{\prime}$ (Mayer \& Butler 1993).

Another method to lipid-correct $\delta^{13} \mathrm{C}$ values uses a mass-balance approach (Fry et al. 2003), and requires information on the $\mathrm{C}: \mathrm{N}$ ratio of untreated samples $(\mathrm{CN})$, pure protein $\left(\mathrm{CN}_{\text {protein }}\right)$, and depletion of lipids relative to protein $D$ :

$$
\delta^{13} \mathrm{C}_{\text {protein }}^{\prime}=\left\{\left(\delta^{13} \mathrm{C} \times \mathrm{CN}\right)+\left[D\left(\mathrm{CN}-\mathrm{CN}_{\text {protein }}\right)\right]\right\} / \mathrm{CN}
$$

$\mathrm{CN}_{\text {protein }}$ was obtained from frozen lipid-extracted skin, i.e. the $\mathrm{C}: \mathrm{N}$ ratio observed when zero extractable lipids remained in a sample, and were calculated separately for beluga, porpoises, and Balaenopteridae (see 'Results'). Given that $D$ was unavailable for whale skin, the mass-balance model was estimated using a $D$ of $6 \%$, as assumed in the M\&M model for marine organisms, as well as using $D$ as estimated by the M\&M model for cetacean skin (overall model) and for each species separately (species-specific models).

Post et al. (2007), using a wide variety of aquatic and terrestrial animals, developed a simplified model using the $\mathrm{C}: \mathrm{N}$ ratio of untreated samples only:

$$
\delta^{13} \mathrm{C}^{1}=\delta^{13} \mathrm{C}-3.32+0.99 \mathrm{CN}
$$

Finally, we also proposed a simple linear model developed from our data, using $\delta^{13} \mathrm{C}$ values of untreated whale skin alone, and compared accuracy with the 3 previous models.

Error effects on mixing models: Effects of errors associated with sample treatment or lipid normalization on results from isotopic mixing models were examined for models with 1 isotope and 2 end sources (Phillips \& Gregg 2003). Differences in percent contribution of end-member $x\left(\Delta_{\% \mathrm{X}}\right)$ for a consumer with a mean error $\Delta_{\text {error }}$ in its isotopic signature were calculated for mean errors of 0.1 to $1.5 \%$ and differences between end-members $\Delta_{\text {sources }}$ of 0.5 to $10 \%$ as follows:

$$
\Delta_{\% \mathrm{X}}=\Delta_{\text {error }} / \Delta_{\text {sources }}
$$

Statistical analyses: Paired $t$-tests $(\alpha=0.05)$ were used to control for individual variation and to test for effects of the various treatments on isotope ratios and trace-element concentrations. Results were cross-validated using a signed rank test on differences when distributions deviated from normality, as determined from a Shapiro-Wilk statistic (Mayer \& Butler 1993). Levene's test for equal variances was used to examine effects of lipid extraction on sample variances, as this test is more robust to deviations from normality than Bartlett's test (SAS Institute 1990). Original data 
and residuals from regression analyses were tested for normality and homoscedasticity. Mean and maximum errors in $\delta^{13} \mathrm{C}$ associated with lipid-normalization models (linear or non-linear) were assessed from distribution of residuals, by calculating their mean absolute error (in \%o) and 95\% confidence limits (CL $=1.96 \times \mathrm{SD}$ ), respectively (Mayer \& Butler 1993). For regression models, we considered the $\delta^{13} \mathrm{C}$ value of frozen lipid-extracted samples as the desirable or true isotopic value for $\mathrm{C}$, and the $\delta^{15} \mathrm{~N}$ value of frozen untreated samples as the reference for $\mathrm{N}$ (Sotiropoulos et al. 2004, Sweeting et al. 2006, Mintenbeck et al. 2008). All statistical analyses were performed separately for $\delta^{13} \mathrm{C}$ and $\delta^{15} \mathrm{~N}$ using the SAS software (SAS Institute 1990) or $\mathrm{R}$ package ( $\mathrm{R}$ Development Core Team 2009).

\section{RESULTS}

\section{Effects of lipid extraction}

Lipid-extracted samples were enriched in ${ }^{13} \mathrm{C}$ over untreated samples $\left(\Delta \delta^{13} \mathrm{C}\right)$ by an average of 1.78 to $2.55 \%$ depending on species group, with the largest effects in Balaenopteridae and the lowest effects in beluga (paired $t$-tests: $t_{\mathrm{s}}=18.2$ to 19.2 ; all $\mathrm{p}<$ 0.0001) (Table 1). Enrichment systematically decreased with increasing $\delta^{13} \mathrm{C}$ values, and in a similar way for the 3 species groups, as indicated by nonzero but similar regression slopes (all $p<0.0001$; Fig. 1). The progressive reduction in effects of lipid extraction with increasing $\delta^{13} \mathrm{C}$ values resulted partly from a decrease in fat content-inferred from a decrease in C:N ratios - with increasing $\delta^{13} \mathrm{C}$ values (Fig. 2). The $y$-axis intercepts were similar for harbor porpoises and Balaenopteridae, but differed from that of beluga. As a result, species-specific models were more adequate, i.e. they resulted in reduced

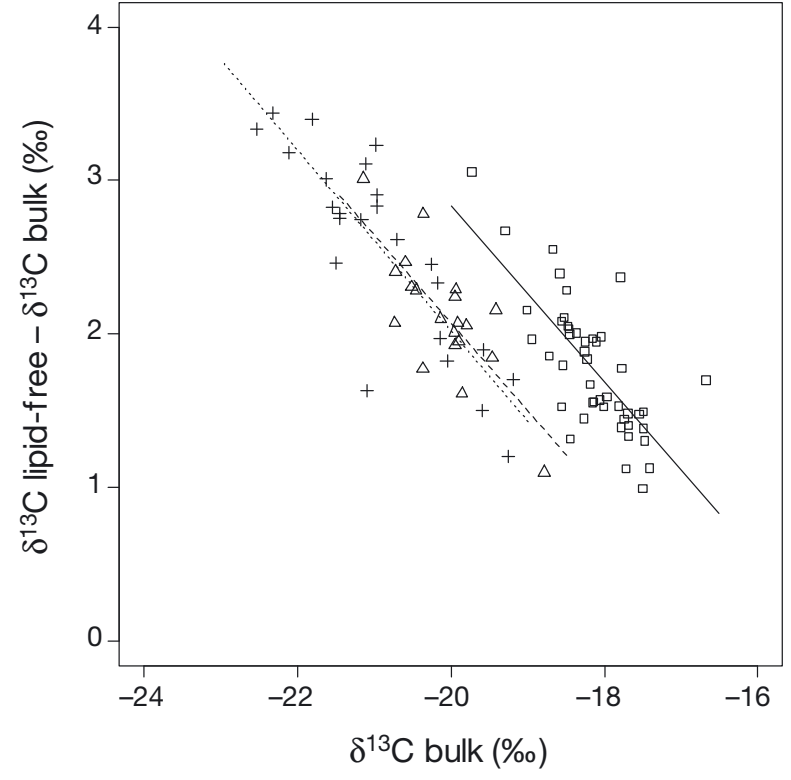

Fig. 1. Effects of lipid extraction from frozen skin samples on $\delta^{13} \mathrm{C}$ values for beluga $(\square$, solid line), harbor porpoise $(\Delta$, dashed line), and Balaenopteridae (+, dotted line). Regression coefficients for each model are presented in Table 2

mean and maximum errors relative to the overall model (Fig. 1, Table 2). Species-specific models had coefficients of determination of 0.53 to 0.71 , and resulted in lipid-normalized $\delta^{13} \mathrm{C}$ values with mean errors of 0.20 to $0.25 \%$, and maximum errors $(95 \%$ CL) of 0.52 to $0.67 \%$, depending on species group (Table 2). Lipid extraction also slightly decreased the variance of $\delta^{13} \mathrm{C}$ values in all 3 groups, although significantly only for Balaenopteridae (Levene's $F=$ 8.66, $\mathrm{p}=0.005)$.

Effects of lipid extraction were smaller but statistically significant for $\delta^{15} \mathrm{~N}$ values, and were toward a mean depletion of $0.14 \%$ in Balaenopteridae, and mean enrichments of $0.30 \%$ and $0.22 \%$ in porpoises

Table 1. Mean $( \pm \mathrm{SD})$ stable-isotope values associated with various treatments of cetacean skin samples. Isotopic values of lipidextracted samples are indicated as $\delta^{13} \mathrm{C}^{\prime}$ and $\delta^{15} \mathrm{~N}^{\prime}$. Reference treatment for each element is indicated in bold. nd: no data

\begin{tabular}{|llccccc|}
\hline Taxon & $\mathrm{n}$ & Treatment & $\delta^{13} \mathrm{C}$ & $\delta^{13} \mathrm{C}^{\prime}$ & $\delta^{15} \mathrm{~N}$ \\
\hline Beluga & 46 & Frozen & $-18.1 \pm 0.5$ & $\mathbf{- 1 6 . 4} \pm \mathbf{0 . 4}$ & $\mathbf{1 6 . 3} \pm \mathbf{0 . 8}$ & $16.5 \pm 0.8$ \\
Delphinapterus leucas & 46 & DMSO rinsed & $-19.0 \pm 0.7$ & $-16.3 \pm 0.5$ & $16.9 \pm 0.9$ & $16.9 \pm 0.9$ \\
& 11 & DMSO no rinse & $-23.2 \pm 0.5$ & nd & $15.2 \pm 0.7$ & nd \\
Harbor porpoise & 20 & Frozen & $-20.1 \pm 0.5$ & $\mathbf{- 1 8 . 0} \pm \mathbf{0 . 3}$ & $\mathbf{1 4 . 4} \pm \mathbf{0 . 7}$ & $14.7 \pm 0.6$ \\
Phocoena phocoena & 20 & DMSO rinsed & $-20.6 \pm 0.5$ & $-18.1 \pm 0.3$ & $14.9 \pm 0.6$ & $15.0 \pm 0.6$ \\
Balaenopteridae & 24 & Frozen & $-20.9 \pm 0.9$ & $\mathbf{- 1 8 . 3} \pm \mathbf{0 . 5}$ & $\mathbf{1 3 . 2} \pm \mathbf{1 . 4}$ & $13.1 \pm 1.4$ \\
& 24 & DMSO rinsed & $-21.6 \pm 1.0$ & $-18.4 \pm 0.5$ & $13.5 \pm 1.4$ & $13.4 \pm 1.4$ \\
Bowhead whale & 37 & Frozen & nd & $-\mathbf{1 9 . 5} \pm \mathbf{0 . 5}$ & nd & $13.2 \pm 0.5$ \\
Balaena mysticetus & 37 & DMSO rinsed & nd & $-19.6 \pm 0.4$ & nd & $13.2 \pm 0.5$ \\
\hline
\end{tabular}


and beluga, respectively (paired $t_{\mathrm{s}}=-2.0$ to 6.4 ; all $\mathrm{p}<$ 0.05 ; Fig. 3). Regression slopes and intercepts were not statistically different from 1 and 0 , respectively, contributing to high model fit for all 3 species groups (Table 3). Predictions of $\delta^{15} \mathrm{~N}$ values of frozen untreated samples from lipid-extracted samples were

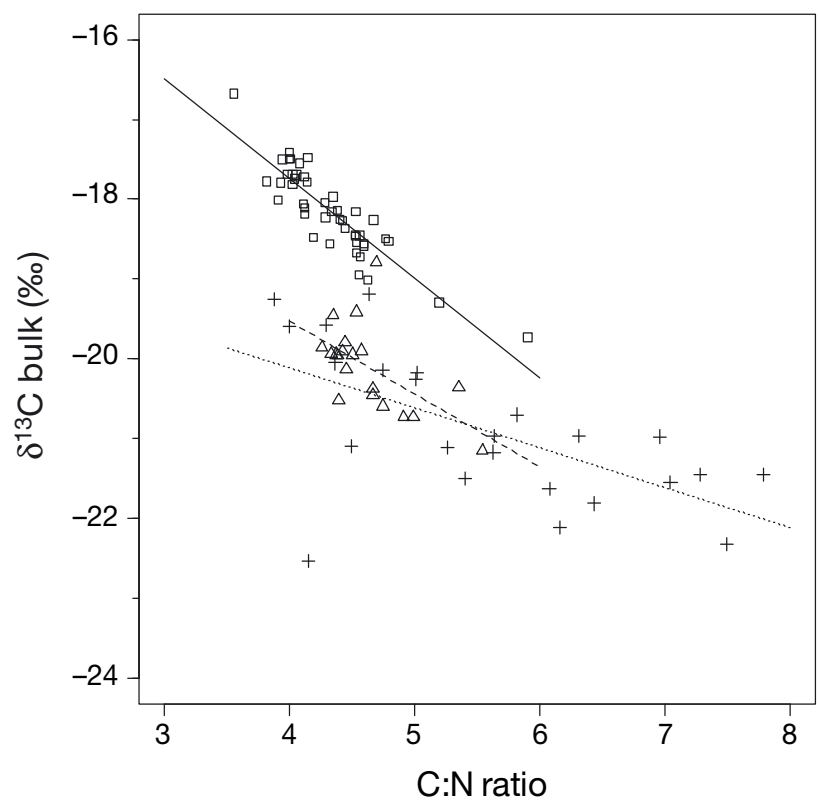

Fig. 2. Relationships between $\mathrm{C}: \mathrm{N}$ ratios and $\delta^{13} \mathrm{C}$ values of frozen, untreated skin for beluga ( $\square$, solid line), harbor porpoise $(\Delta$, dashed line), and Balaenopteridae $(+$, dotted line $)$ associated with a mean error of 0.14 to $0.25 \%$, and maximum error (95\% CL) of 0.40 to $0.67 \%$, depending on groups (Table 3). Lipid extraction had no effect on variance of $\delta^{15} \mathrm{~N}$ values (Levene's $F$, all $\mathrm{p}>0.05$ ).

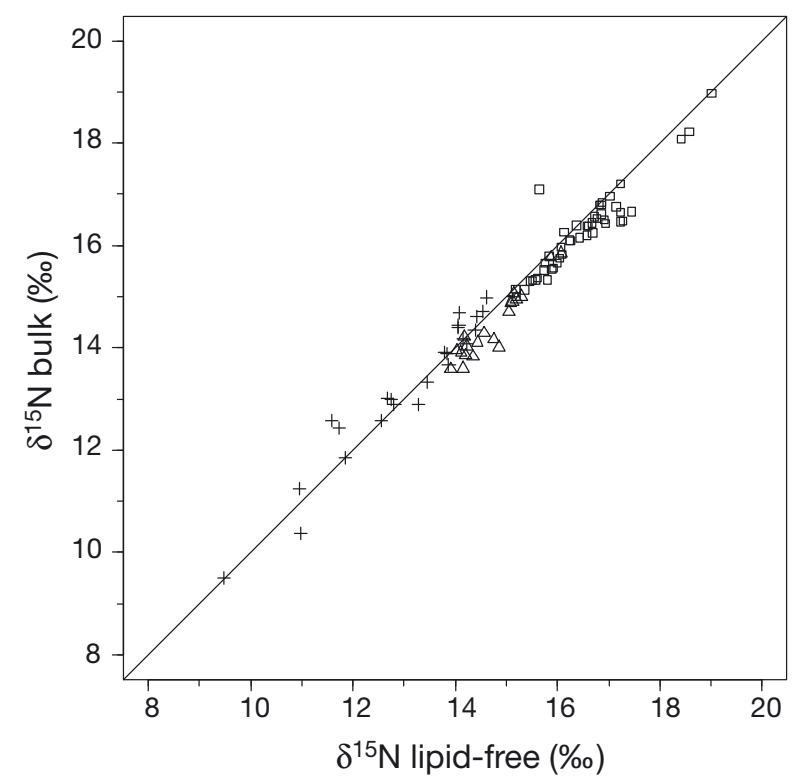

Fig. 3. Effects of lipid extraction from frozen skin samples on $\delta^{15} \mathrm{~N}$ values for beluga $(\square)$, harbor porpoise $(\Delta)$, and Balaenopteridae $(+)$. The line corresponds to no difference between lipid-extracted and non-extracted samples. Regression coefficients for predicting $\delta^{15} \mathrm{~N}$ values of frozen untreated samples from lipid-extracted samples are presented in Table 3

Table 2. Parameter estimates of linear $\left(y=\beta \times \delta^{13} C_{\text {untreated }}+\alpha_{0}\right)$ and non-linear (McConnaughey \& McRoy 1979; Eqs. $\left.1 \& 2\right)$ models for lipid normalization of $\delta^{13} \mathrm{C}$ values of cetacean skin. The predicted term y represents differences in $\delta^{13} \mathrm{C}$ between lipidextracted and untreated skin. ${ }^{*}$ Statistical significance at $\alpha=0.05$. CL: confidence limits; $D$ : isotopic difference between pure lipid and pure protein; EF: model efficiency; I: a constant; SEM: standard error of the mean

\begin{tabular}{|c|c|c|c|c|c|}
\hline Species group & Model & Coefficient \pm SEM & $\begin{array}{c}\mathrm{r}^{2} \\
\text { or EF }\end{array}$ & $\begin{array}{l}\text { Mean absolute } \\
\text { error (\%) }\end{array}$ & $\begin{array}{c}95 \% \mathrm{CL} \\
\text { of residuals (\%o) }\end{array}$ \\
\hline Beluga & $\begin{array}{c}\text { Linear } \\
\text { Non-linear }\end{array}$ & $\begin{aligned} \beta & =-0.572 \pm 0.080^{*} \\
\alpha & =-8.599 \pm 1.444^{*} \\
D & =6.531 \pm 0.234^{*} \\
I & =0.003 \pm 0.007\end{aligned}$ & $\begin{array}{l}0.53 \\
0.93^{\mathrm{a}}\end{array}$ & $\begin{array}{l} \pm 0.22 \\
\pm 0.25^{\mathrm{a}}\end{array}$ & $\begin{array}{l} \pm 0.56 \\
\pm 0.67^{\mathrm{a}}\end{array}$ \\
\hline Harbor porpoise & $\begin{array}{c}\text { Linear } \\
\text { Non-linear }\end{array}$ & $\begin{aligned} \beta & =-0.573 \pm 0.116^{*} \\
\alpha & =-9.393 \pm 2.331^{*} \\
D & =6.705 \pm 0.281^{*} \\
I & =0.005 \pm 0.009\end{aligned}$ & $\begin{array}{c}0.55 \\
0.95^{\mathrm{a}}\end{array}$ & $\begin{array}{l} \pm 0.20 \\
\pm 0.24^{\mathrm{a}}\end{array}$ & $\begin{array}{l} \pm 0.52 \\
\pm 0.66^{\mathrm{a}}\end{array}$ \\
\hline Balaenopteridae & $\begin{array}{l}\text { Linear } \\
\text { Non-linear }\end{array}$ & $\begin{aligned} \beta & =-0.588 \pm 0.077^{*} \\
\alpha & =-9.742 \pm 1.614^{*} \\
D & =6.219 \pm 0.266^{*} \\
I & =-0.002 \pm 0.012\end{aligned}$ & $\begin{array}{l}0.71 \\
0.93^{\mathrm{a}}\end{array}$ & $\begin{array}{l} \pm 0.25 \\
\pm 0.31^{\mathrm{a}}\end{array}$ & $\begin{array}{l} \pm 0.67 \\
\pm 0.98^{\mathrm{a}}\end{array}$ \\
\hline All species & $\begin{array}{c}\text { Linear } \\
\text { Non-linear }\end{array}$ & $\begin{aligned} \beta & =-0.331 \pm 0.027^{*} \\
\alpha & =-4.334 \pm 0.531^{*} \\
D & =6.386 \pm 0.146^{*} \\
I & =0.004 \pm 0.005\end{aligned}$ & $\begin{array}{c}0.62 \\
0.96^{\mathrm{a}}\end{array}$ & $\begin{array}{l} \pm 0.28 \\
\pm 0.44^{\mathrm{a}}\end{array}$ & $\begin{array}{l} \pm 0.71 \\
\pm 0.60^{\mathrm{a}}\end{array}$ \\
\hline
\end{tabular}


Table 3. Parameter estimates of linear regressions $(y=\beta x+\alpha)$ to predict $\delta^{15} \mathrm{~N}$ values of untreated samples $(y)$ from lipid-extracted cetacean skin $(x)$. Note that neither slopes $(\beta)$ nor $y$-intercepts $(\alpha)$ are statistically different from 1 and 0, respectively. CL: confidence limits, SEM: standard error of the mean

\begin{tabular}{|llccc|}
\hline Species group & Coefficient \pm SEM & $\mathrm{r}^{2}$ adj & $\begin{array}{c}\text { Mean } \\
\text { absolute } \\
\text { error (\%) }\end{array}$ & $\begin{array}{c}95 \% \mathrm{CL} \\
\text { of residuals } \\
(\%)\end{array}$ \\
\hline Beluga & $\begin{array}{l}\beta=0.894 \pm 0.056 \\
\alpha=1.535 \pm 0.919\end{array}$ & 0.85 & \pm 0.19 & \pm 0.61 \\
Harbor porpoise & $\beta=1.037 \pm 0.079$ & 0.90 & \pm 0.14 & \pm 0.40 \\
& $\begin{array}{l}\alpha=-0.847 \pm 1.165 \\
\text { Balaenopteridae }\end{array}$ & & & \\
& $\alpha=0.998 \pm 0.053$ & 0.94 & \pm 0.25 & \pm 0.67 \\
\hline
\end{tabular}

maximum errors associated with lipid normalization of $\delta^{13} \mathrm{C}$ values $\left(\delta^{13} \mathrm{C}^{\prime}\right)$ were similar for M\&M models specific to beluga and porpoises, but lower than for the model specific to Balaenopteridae (Table 2). Using the overall non-linear model in place of species-specific models resulted in mean biases in $\delta^{13} \mathrm{C}^{\prime}$ of $+0.11 \%$ o for Balaenopteridae, $-0.11 \%$ o for harbor porpoises, and $+0.03 \%$ for beluga. The non-linear M\&M models using both $\mathrm{C}: \mathrm{N}$ ratios and $\delta^{13} \mathrm{C}$ values of untreated samples as input variables resulted in consistently higher mean and maximum errors than species-specific linear regressions using $\delta^{13} \mathrm{C}$ values alone (Table 2).

The model proposed by Post et al. (2007) did not appropriately predict $\delta^{13} \mathrm{C}$ values of lipid-free whale skin (Fig. 5), probably because it assumed a linear relationship between $\mathrm{C}: \mathrm{N}$ and $\Delta \delta^{13} \mathrm{C}$, while this relationship was in fact non-linear for this tissue and group of species (Fig. 4). In contrast, the mass-balance model of Fry et al. (2003) tended to underestimate lipid-free $\delta^{13} \mathrm{C}$ values by 0.08 to $0.30 \%$, although less so for Balaenopteridae (Table 4). Acknowledging this deviance, mean absolute errors were comparable among species when using cetacean- or speciesspecific $D$ values. Mean errors, however, remained higher for all 3 species groups than when using the species-specific linear models based on $\delta^{13} \mathrm{C}$ alone. While these results would suggest a better performance of the linear model, the latter resulted in larger errors than the Fry model.

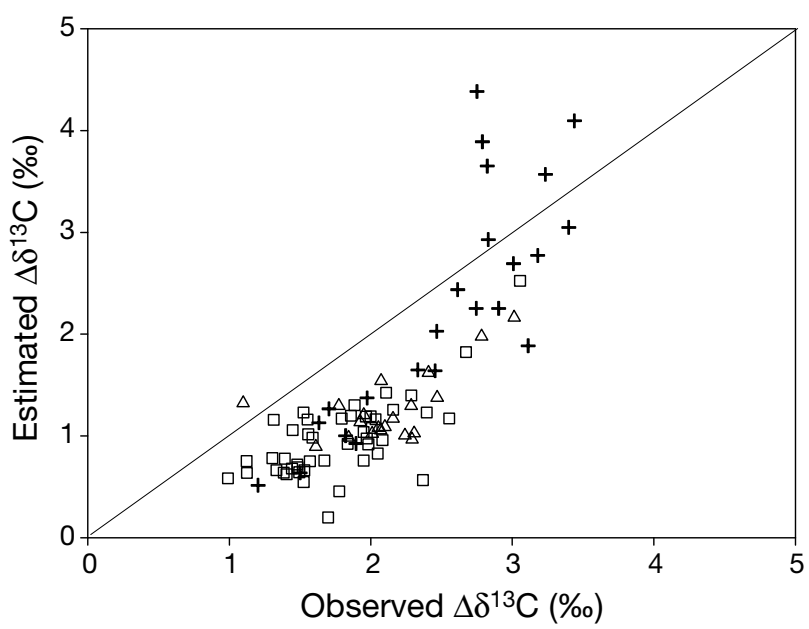

Fig. 5. Relationships between the difference in $\delta^{13} \mathrm{C}$ of lipidextracted and untreated skin $\left(\Delta \delta^{13} \mathrm{C}\right)$ estimated using Eq. (3) of Post et al. (2007) for aquatic species $\left(\Delta \delta^{13} \mathrm{C}=-3.32+0.99 \times\right.$ $\mathrm{C}: \mathrm{N})$ and $\Delta \delta^{13} \mathrm{C}$ measured in the present study for beluga ( $\square$ ), harbor porpoise $(\Delta)$, and Balaenopteridae $(+)$ 
Table 4. Comparison of model results for lipid normalization of $\delta^{13} \mathrm{C}$ values obtained using the linear model based on $\delta^{13} \mathrm{C}$ bulk only (Table 2), and the mass-balance approach (Fry et al. 2003) while varying ${ }^{13} \mathrm{C}$ depletion of pure lipid relative to pure protein $(D)$ according to values proposed by McConnaughey \& McRoy (1979) (M\&M; 6\%) for muscle or whole body of marine vertebrates and invertebrates and Sweeting et al. (2006) (7\%) for muscle of aquatic fish, or those obtained through modeling (using the M\&M approach) for cetacean skin (average: $6.4 \%$ ) or for skin of specific cetacean species. CL: confidence limits. Porpoise: harbor porpoise; Balaen.: Balaenopteridae

\begin{tabular}{|c|c|c|c|c|c|c|c|c|c|c|}
\hline \multirow[t]{2}{*}{ Model } & \multirow[t]{2}{*}{$D(\%)$} & \multicolumn{3}{|c|}{$\begin{array}{l}\text { Mean deviance } \\
\text { from model (\%o) }\end{array}$} & \multicolumn{3}{|c|}{$\begin{array}{l}\text { Mean absolute error } \\
\text { about the mean }(\%) \text { ) }\end{array}$} & \multicolumn{3}{|c|}{$\begin{array}{c}95 \% \text { CL } \\
\text { about the mean (\%o) }\end{array}$} \\
\hline & & Beluga & Porpoise & Balaen. & Beluga & Porpoise & Balaen. & Beluga & Porpoise & Balaen. \\
\hline \multicolumn{2}{|l|}{ Simple linear } & 0.00 & 0.00 & 0.00 & \pm 0.22 & \pm 0.20 & \pm 0.25 & \pm 0.56 & \pm 0.52 & \pm 0.67 \\
\hline \multirow[t]{2}{*}{ Mass balance } & $\begin{array}{l}6.0 \\
6.4 \\
7.0\end{array}$ & $\begin{array}{r}-0.25 \\
-0.14 \\
0.01\end{array}$ & $\begin{array}{r}-0.29 \\
-0.17 \\
0.01\end{array}$ & $\begin{array}{r}-0.06 \\
0.10 \\
0.35\end{array}$ & $\begin{array}{l} \pm 0.32 \\
\pm 0.28 \\
\pm 0.25\end{array}$ & $\begin{array}{l} \pm 0.38 \\
\pm 0.30 \\
\pm 0.23\end{array}$ & $\begin{array}{l} \pm 0.26 \\
\pm 0.27 \\
\pm 0.40\end{array}$ & $\begin{array}{l} \pm 0.52 \\
\pm 0.49 \\
\pm 0.49\end{array}$ & $\begin{array}{l} \pm 0.42 \\
\pm 0.43 \\
\pm 0.50\end{array}$ & $\begin{array}{l} \pm 0.43 \\
\pm 0.51 \\
\pm 0.70\end{array}$ \\
\hline & cies-specific & -0.12 & -0.08 & 0.02 & \pm 0.27 & \pm 0.25 & \pm 0.26 & \pm 0.48 & \pm 0.47 & \pm 0.45 \\
\hline
\end{tabular}
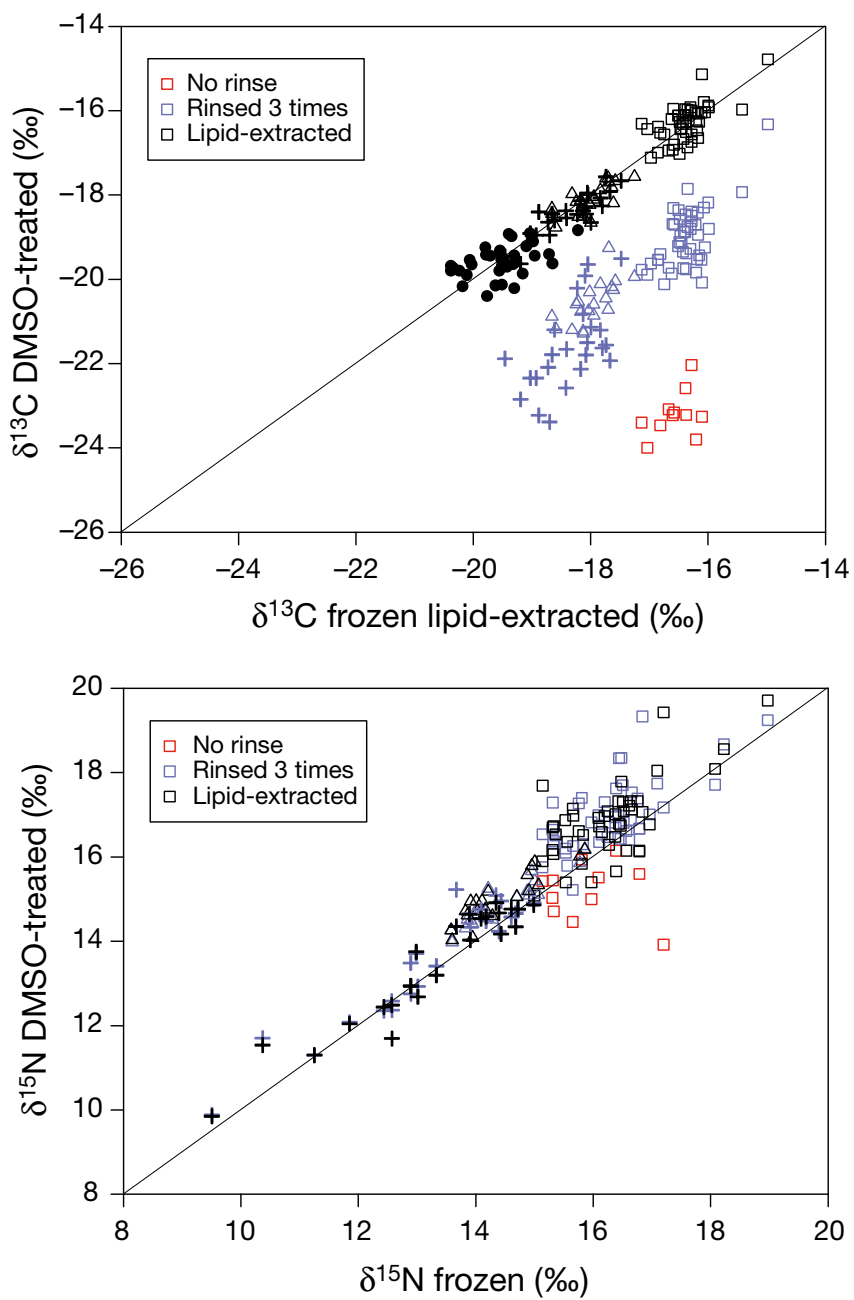

Fig. 6. Effects of rinsing and lipid extraction of DMSO-preserved samples on (a) $\delta^{13} \mathrm{C}$ and (b) $\delta^{15} \mathrm{~N}$ values for beluga ( $\square$ ), harbor porpoise $(\Delta)$, Balaenopteridae $(+)$, and bowhead whale (๑). Reference levels are isotopic values for skin directly frozen at $-20^{\circ} \mathrm{C}$ followed $\left(\delta^{13} \mathrm{C}\right)$ or not $\left(\delta^{15} \mathrm{~N}\right)$ by lipid extraction. The solid line represents values expected if there is no difference between treatments
Effects of DMSO preservation

\section{Stable isotopes}

Beluga skin treated with DMSO had $\delta^{13} \mathrm{C}$ and $\delta^{15} \mathrm{~N}$ values depleted relative to frozen samples (paired $t$-tests: $\mathrm{df}=10 ; \mathrm{p}=0.001$ and 0.04 , respectively) (Fig. 6). Depletion was on average of $6.6 \%$ relative to $\delta^{13} \mathrm{C}$ of frozen lipid-extracted samples $(\mathrm{SD}=0.5 \%$; range: -5.8 to $7.6 \%)$, and of $0.7 \%$ ( $\mathrm{SD}=1.0 \%$; range: -0.3 to $-3.2 \%$ ) relative to $\delta^{15} \mathrm{~N}$ of frozen untreated samples (Table 1). Rinsing of DMSO-preserved samples prior to isotope analyses reduced the depletion in ${ }^{13} \mathrm{C}$ to $2.6 \%$ ( $\mathrm{SD}=0.6 \%$; range: -1.3 to $-4.0 \%$ ) relative to frozen lipid-extracted samples, and resulted in an enrichment of $0.7 \%$ o $(\mathrm{SD}=0.7 \%$; range: -0.4 to $2.5 \%$ ) in ${ }^{15} \mathrm{~N}$ over values for frozen untreated samples $(\mathrm{df}=45$, each $\mathrm{p}<0.0001)$. Similar results were obtained for harbor porpoises $\left(\Delta \delta^{13} \mathrm{C}=-2.6 \pm 0.4 \%\right.$; $\Delta \delta^{15} \mathrm{~N}=0.2 \pm 0.3 \%$, df $=19$; both $\left.\mathrm{p}<0.0001\right)$ and Balaenopteridae $\left(\Delta \delta^{13} \mathrm{C}=-3.2 \pm 0.8 \% ; \Delta \delta^{15} \mathrm{~N}=0.5 \pm\right.$ $0.3 \%$, df $=23$; both $\mathrm{p}<0.003$ ) when comparing DMSO-rinsed samples to frozen standards for each element (Table 1). Rinsing methods using 3 washes or a $24 \mathrm{~h}$ soak in distilled water prior to DMSO removal resulted in values of $\delta^{13} \mathrm{C}\left(t_{\mathrm{s}}=0.89, \mathrm{df}=9, \mathrm{p}=0.40\right)$ and $\delta^{15} \mathrm{~N}\left(t_{\mathrm{s}}=0.86 ; \mathrm{df}=9, \mathrm{p}=0.41\right)$ that were comparable (mean difference: 0.02 and $0.03 \%$, respectively) once samples were lipid-extracted.

Lipid extraction from DMSO-preserved samples restored $\mathrm{C}$ isotopic signatures as if samples had been frozen and lipid-extracted in all 4 species groups, including bowhead whales (mean difference: -0.10 to $0.09 \%$, paired $t$-tests: all $\mathrm{p}=0.07$ to 0.23 ; Fig. 6, Table 1). However, a mean enrichment in $\delta^{15} \mathrm{~N}$ values of 0.16 to $0.60 \%$ depending on species groups persisted after lipid extraction of DMSO-preserved samples when compared with frozen untreated sam- 
ples ( $\mathrm{p}<0.001$ for beluga and harbor porpoises; $\mathrm{p}=$ 0.08 for Balaenopteridae; Fig. 6, Table 1). The residual effect from lipid extraction of DMSO-preserved samples on $\delta^{15} \mathrm{~N}$ values could not be tested for bowhead whales due to the lack of frozen untreated samples for this species. The comparison of lipidextracted samples that were or were not preserved in DMSO indicated no effect of the preservative on sample variance for $\delta^{13} \mathrm{C}$ or $\delta^{15} \mathrm{~N}$ values (Levene's $F_{\text {, }}$ all $\mathrm{p}>0.05)$.

The complete restoration of $\mathrm{C}$ signatures and nearcomplete restoration of $\mathrm{N}$ signatures after lipid extraction was reflected in the linear regressions by a slope approaching 1 and a lack of statistical significance of intercepts (not different from zero) for both isotopes and all species except beluga (Table 4, Fig. 6). Applying these regressions for restoring $\mathrm{C}$ signatures as if samples had been frozen and lipid-extracted resulted in mean errors of 0.15 to $0.35 \%$ and maximum errors (95\% CL) of 0.43 to $0.56 \%$ in $\delta^{13} \mathrm{C}$ values (Table 5). These errors were similar or smaller than those associated with the lipid normalization of untreated samples (Table 2), indicating that preservation in DMSO did not add to errors related to lipid normalization. In contrast, restoration of $\delta^{15} \mathrm{~N}$ values of DMSO-preserved lipid-extracted samples as if samples had been untreated were associated with mean and maximum errors that were larger than for $\delta^{13} \mathrm{C}$ or lipidnormalized values at 0.25 to $0.47 \%$ ond 0.56 to $1.16 \%$, respectively (Table 5).
Trace elements

For 9 of 15 trace elements, the absence of a relationship between concentrations observed in frozen and DMSO-preserved samples (i.e. slope not different from $0 ; \mathrm{p}>0.05 ; \mathrm{r}^{2}{ }_{\text {adj }}<0.03$ ) indicated the inability to accurately predict trace element concentrations from DMSO-preserved samples that would have been measured if samples had been frozen directly (Fig. 7). The predictive power of linear regressions was higher $\left(\mathrm{r}^{2}{ }_{\text {adj }}=0.17\right.$ to 0.48$)$ for the following trace elements: ${ }^{51} \mathrm{~V},{ }^{59} \mathrm{Co},{ }^{66} \mathrm{Zn},{ }^{75} \mathrm{As},{ }^{82} \mathrm{Se}$, and ${ }^{111} \mathrm{Cd}$. However, heteroscedasticity of residuals was detected in all 6 cases, thereby violating model assumptions. Concentrations were larger in frozen samples than in DMSO-preserved samples for ${ }^{51} \mathrm{~V}$ and ${ }^{59} \mathrm{Co}$, whereas the converse was observed for ${ }^{75} \mathrm{As}$ and ${ }^{82} \mathrm{Se}$ and for 6 of the 9 cases where no significant relationships were observed between the 2 treatments. In the latter cases, trace elements were in concentrations several orders of magnitude higher in DMSO-preserved samples than in frozen samples.

\section{Error effects on isotopic mixing models}

The effects of errors associated with the various treatments and normalization models on isotopic mixing results were largely dependent on isotopic distances between sources (Fig. 8). Simulations indicate

Table 5. Parameter estimates for predicting $\delta^{13} \mathrm{C}_{\text {lipid-free }}$ and $\delta^{15} \mathrm{~N}_{\text {bulk }}$ values $(y)$ from DMSO-preserved lipid-extracted samples ( $x$ ) using linear regressions. * Slopes $(\alpha)$ or $y$-intercepts $(\beta)$ that are statistically different from 1 and 0 , respectively. CL: confidence limits, SEM: standard error of the mean

\begin{tabular}{|c|c|c|c|c|c|}
\hline Species group & $y$ & Coefficient \pm SEM & $\mathrm{r}_{\text {adj }}^{2}$ & $\begin{array}{c}\text { Mean absolute } \\
\text { error }(\%)\end{array}$ & $\begin{array}{c}95 \% \mathrm{CL} \\
\text { of residuals }(\%)\end{array}$ \\
\hline All species & $\begin{array}{c}\delta^{13} \mathrm{C}_{\text {lipid-free }} \\
\delta^{15} \mathrm{~N}_{\text {bulk }}\end{array}$ & $\begin{array}{l}\beta=0.917 \pm 0.022^{*} \\
\alpha=-1.463 \pm 0.388^{*} \\
\beta=0.904 \pm 0.023 \\
\alpha=1.161 \pm 0.349^{*}\end{array}$ & $\begin{array}{l}0.93 \\
0.92\end{array}$ & $\begin{array}{l} \pm 0.27 \\
\pm 0.33\end{array}$ & $\begin{array}{l} \pm 0.67 \\
\pm 0.95\end{array}$ \\
\hline Beluga & $\begin{array}{c}\delta^{13} \mathrm{C}_{\text {lipid-free }} \\
\delta^{15} \mathrm{~N}_{\text {bulk }}\end{array}$ & $\begin{array}{l}\beta=0.532 \pm 0.095^{*} \\
\alpha=-7.712 \pm 1.547^{*} \\
\beta=0.615 \pm 0.097^{*} \\
\alpha=5.901 \pm 1.641^{*}\end{array}$ & $\begin{array}{l}0.40 \\
0.46\end{array}$ & $\begin{array}{l} \pm 0.22 \\
\pm 0.47\end{array}$ & $\begin{array}{l} \pm 0.56 \\
\pm 1.16\end{array}$ \\
\hline Harbor porpoise & $\begin{array}{c}\delta^{13} \mathrm{C}_{\text {lipid-free }} \\
\delta^{15} \mathrm{~N}_{\text {bulk }}\end{array}$ & $\begin{array}{l}\beta=0.819 \pm 0.153 \\
\alpha=-3.180 \pm 2.767 \\
\beta=0.987 \pm 0.110 \\
\alpha=-0.409 \pm 1.664\end{array}$ & $\begin{array}{l}0.59 \\
0.81\end{array}$ & $\begin{array}{l} \pm 0.15 \\
\pm 0.25\end{array}$ & $\begin{array}{l} \pm 0.43 \\
\pm 0.56\end{array}$ \\
\hline Balaenopteridae & $\begin{array}{c}\delta^{13} \mathrm{C}_{\text {lipid-free }} \\
\delta^{15} \mathrm{~N}_{\text {bulk }}\end{array}$ & $\begin{array}{l}\beta=0.911 \pm 0.106 \\
\alpha=-1.548 \pm 1.963 \\
\beta=0.960 \pm 0.066 \\
\alpha=0.371 \pm 0.893\end{array}$ & $\begin{array}{l}0.76 \\
0.90\end{array}$ & $\begin{array}{l} \pm 0.21 \\
\pm 0.33\end{array}$ & $\begin{array}{l} \pm 0.49 \\
\pm 0.85\end{array}$ \\
\hline Bowhead whale & $\delta^{13} \mathrm{C}_{\text {lipid-free }}$ & $\begin{array}{l}\beta=0.649 \pm 0.196 \\
\alpha=-6.782 \pm 3.841\end{array}$ & 0.22 & \pm 0.35 & \pm 0.86 \\
\hline
\end{tabular}


that errors in the range of the mean absolute errors observed in the present study, i.e. from 0.14 to $0.47 \%$, resulted in biases of $>20$ to $50 \%$ in predicted contributions when prey sources differed isotopically by $1 \%$ or less. Biases decreased to $18 \%$ or less when prey occupied distinct trophic levels, i.e. assuming they differed by $\sim 3 \%$ or more.

\section{DISCUSSION}

\section{Lipid extraction and preservative effects}

The effects of lipid extraction and DMSO preservation on isotope ratios and trace elements depend on tissue composition, as well as chemical properties of ele-
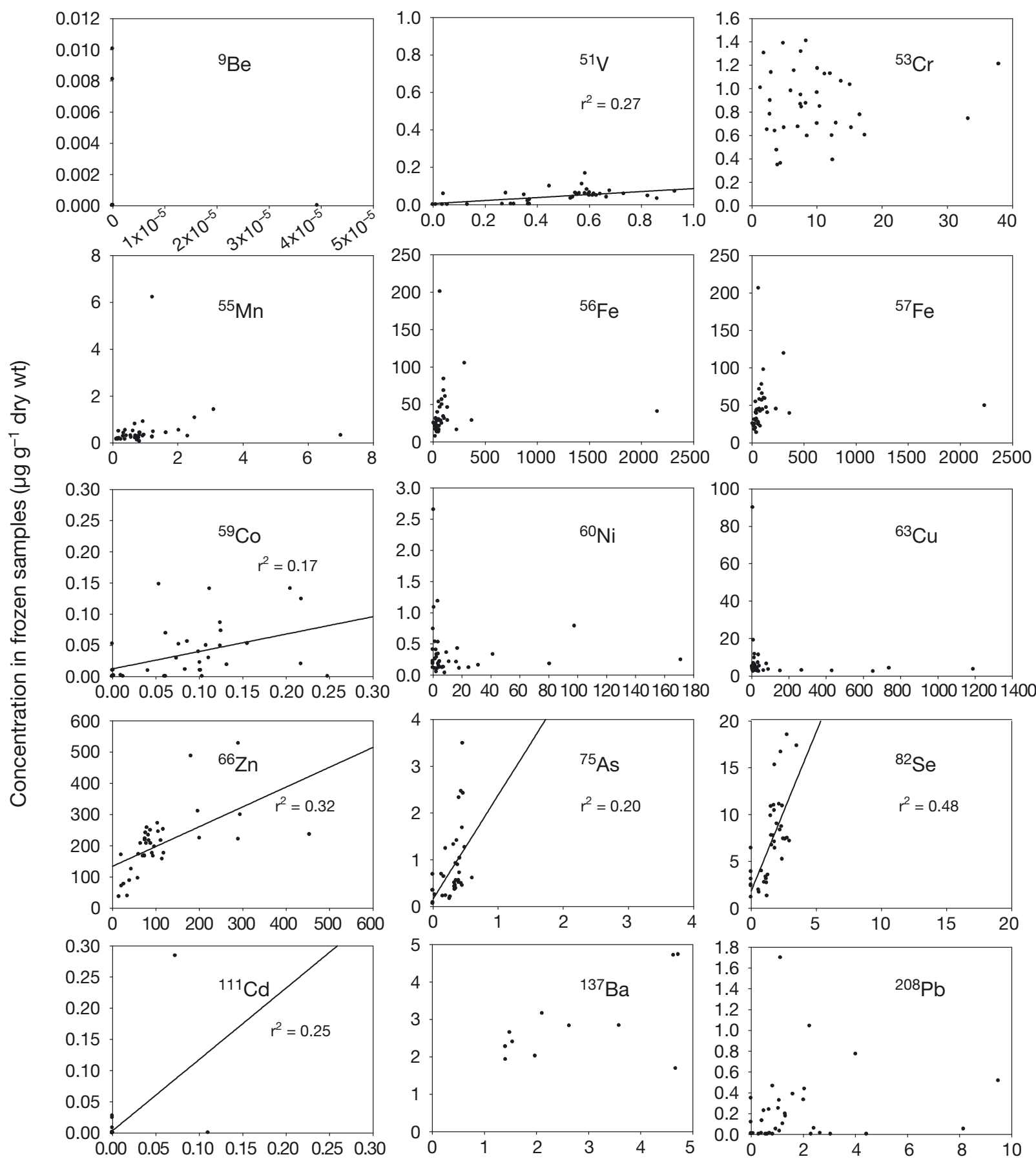

Concentration in DMSO-preserved rinsed samples ( $\left.\mu \mathrm{g} \mathrm{g}^{-1} \mathrm{dry} w \mathrm{w}\right)$

Fig. 7. Delphinapterus leucas. Effects of DMSO preservation on concentrations of 14 trace elements for beluga. Regression curves are presented for significant relationships only 


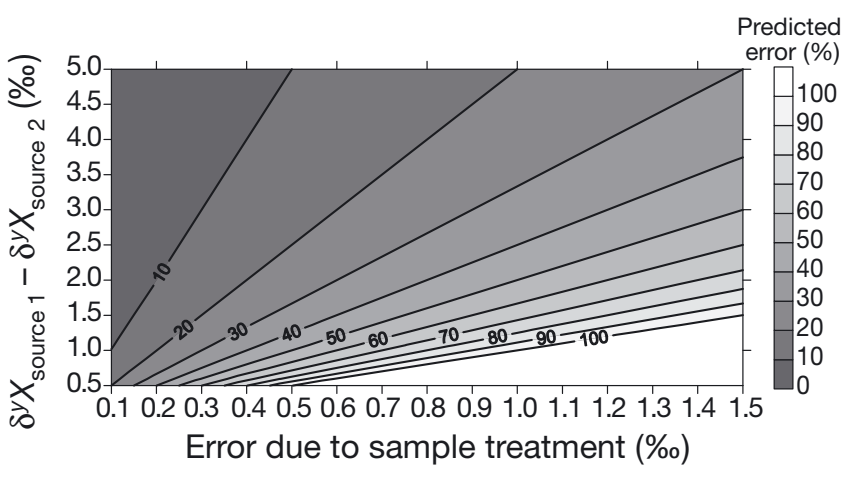

Fig. 8. Predicted error (in \%) introduced into a 2-end-member mixing model (isoclines) for various levels of error due to sample treatment ( $x$-axis) and end members with various degrees of distinctiveness ( $y$-axis)

ments and solvents. Lipids are depleted in ${ }^{13} \mathrm{C}$ relative to carbohydrates and proteins (Degens et al. 1968, DeNiro \& Epstein 1977, Smyntek et al. 2007). Lipid extraction caused an enrichment of $\delta^{13} \mathrm{C}$ values that was within the range of those from a variety of tissues and aquatic organisms. The magnitude of ${ }^{13} \mathrm{C}$ depletion varied among studies, primarily as a result of fat content, with lipid-rich tissues generally showing the largest depletions (Todd et al. 1997, Pinnegar \& Polunin 1999, Kurle \& Worthy 2002, Schlechtriem et al. 2003, Sotiropoulos et al. 2004, Kiljunen et al. 2006, Murry et al. 2006, Sweeting et al. 2006, Bodin et al. 2007, Post et al. 2007, Ricca et al. 2007, Smyntek et al. 2007, Barrow et al. 2008, Logan \& Lutcavage 2008, Logan et al. 2008, Mintenbeck et al. 2008). In these studies, the effects of lipid extraction on $\delta^{15} \mathrm{~N}$ values were more variable but were generally toward a mean, not always significant, enrichment of $\leq 1.6 \%$, a range that encompassed values obtained in the present study. Mechanisms leading to $\mathrm{N}$ loss (Søreide et al. 2006) and $\delta^{15} \mathrm{~N}$ enrichment of tissues require further investigation. One explanation is leaching of isotopically light nitrogenous cell components (e.g. amino acids associated with structural fat or nitrogenous wastes from cellular respiration of proteins; Bearhop et al. 2000) through association with extraction solvents not specific to lipids but to polar and non-polar compounds. The use of less-polar solvents for lipid extraction was proposed as a means to reduce undesired leaching of nitrogenous compounds (e.g. Degens et al. 1968, Schlechtriem et al. 2003, Sotiropoulos et al. 2004, Søreide et al. 2006, Sweeting et al. 2006), but was recently proven to be inefficient in reaching this goal (Logan \& Lutcavage 2008).

DMSO is a relatively compact molecule and binds to a variety of tissue constituents including proteins, carbohydrates, nucleic acids, and ionic substances (Jacob \& Herschler 1975, Szmant 1975). DMSO also makes hydrogen bonds with water molecules, and affects cell membrane structure by increasing permeability (Gordeliy et al. 1998). A direct incorporation of isotopically light $\mathrm{C}$ from DMSO $\left(\mathrm{C}_{2} \mathrm{H}_{6} \mathrm{SO}\right)$ through binding with tissue constituents, combined possibly with a loss of molecules containing the heavier isotope (see Gearing 1991), may have caused the observed $\delta^{13} \mathrm{C}$ depletion of DMSO-preserved samples, an effect also documented in previous studies (Hobson et al. 1997, Todd et al. 1997, Wanek et al. 2001, Barrow et al. 2008). An assumption underlying this hypothesis, which could not be verified given that the isotopic signature of DMSO was not measured in our study, is that DMSO was isotopically lighter in ${ }^{13} \mathrm{C}$ than skin. In contrast with ${ }^{13} \mathrm{C}$, depletion in ${ }^{15} \mathrm{~N}$ was unlikely related to direct incorporation of DMSO as the latter contains no $\mathrm{N}$. The ${ }^{15} \mathrm{~N}$ depletion, which was also documented for bird muscle (Hobson et al. 1997) but not as clearly for turtle epidermis (Barrow et al. 2008), might have been caused by hydrolysis and leaching of isotopically heavy cell constituents through a DMSO-induced increase in membrane permeability. The depletion observed in ${ }^{13} \mathrm{C}$ and ${ }^{15} \mathrm{~N}$ was unlikely related to incorporation of EDTA into tissue as proposed by Hobson et al. (1997) because this additive was not used in the present study. Water rinsing of DMSO-preserved samples and lipid extraction probably evacuated isotopically light compounds, and led to the observed progressive enrichment of $\delta^{13} \mathrm{C}$ and $\delta^{15} \mathrm{~N}$.

The effects of aqueous organic solvents on trace element concentrations were not unexpected given the hydrophilic nature of metal ions; however, they varied considerably among solvents and elements, and were previously undocumented for DMSO (e.g. Gibbs et al. 1974, Hamanaka 1981, Renaud et al. 1995, Bischoff et al. 2008). DMSO had an inconsistent and unpredictable effect on trace element concentrations in cetacean skin, although in most cases, effects were towards greater elemental concentrations in DMSOpreserved than frozen skin, i.e. a positive contamination. Tissue enrichment in trace elements might have resulted from various sources of contamination (Renaud et al. 1995). Trace elements are often used in the production of chemical salts such as DMSO or other products. However, the DMSO solution used in the present study was not analyzed for trace element concentrations, preventing assessment of its relative contribution as a source of contamination. Trace elements might also be a constituent of glass vials; addition of an aqueous solvent binding to hydrophilic metal ions might mobilize them and enrich tissues through penetration of solvent. Our results emphasize the importance of adequate care at all steps of sample collection, handling, and storage when dealing with trace elements (Nriagu et al. 1993) and suggest that DMSO-preserved 
tissues are not appropriate for trace element analysis. These conclusions could be revisited if it was determined that DMSO salts are not a source of contamination, in which case, a strict control of other sources of contamination would be necessary.

Chemical treatment of samples resulted in similar, although not identical, effects on isotopic signatures across cetacean species. These variations likely arose from differences in skin structure and thickness among species (Sokolov 1982). Skin of Balaenidae, including bowhead whales, shares characteristics of both odontocetes and Balaenopteridae (Sokolov 1960). The dermis (excluding subcutaneous fat), which is composed mostly of proteins (collagen and elastin fibers), is usually thin or absent in cetaceans but is particularly thick in bowhead whales and Delphinapteridae such as beluga reaching 3 to $5 \mathrm{~mm}$ in thickness (Bonin \& Vladykov 1940, Sokolov 1982, Haldiman \& Tarpley 1993). Similarly, thickness of the epidermis reaches 5 to $12 \mathrm{~mm}$ in beluga and 15 to $24 \mathrm{~mm}$ in bowhead whales, compared to 2 to $3 \mathrm{~mm}$ in finback and minke whales, 1.5 to $5.5 \mathrm{~mm}$ in humpback whales, 1 to $3 \mathrm{~mm}$ in harbor porpoises, and 1 to $8 \mathrm{~mm}$ in other odontocetes (Bonin \& Vladykov 1940, Giacometti 1967, Harrison \& Thurley 1974, Ling 1974, Sokolov 1982, Haldiman et al. 1985, Jones \& Pfeiffer 1994). Penetration of DMSO as well as extraction of this salt with lipids (and attached nitrogenous compounds) may be facilitated for species with thinner epidermis and a lesser amount of connective protein-rich tissue. More complete and homogeneous extraction of DMSO and lipids probably explained the smaller errors in corrected $\delta^{13} \mathrm{C}$ and $\delta^{15} \mathrm{~N}$ values observed for porpoises and Balaenopteridae, as well as the lack of residual effect of DMSO on $\delta^{13} \mathrm{C}$ in these 2 species groups compared with beluga (Table 5). The slight $\delta^{15} \mathrm{~N}$ depletion of Balaenopteridae skin following lipid extraction as opposed to enrichment in porpoises and beluga, and lesser $\delta^{15} \mathrm{~N}$ enrichment following DMSO extraction compared to the 2 odontocetes, might result from a combination of phenomena, but largely from reduced opportunities for leaching of light proteins.

\section{When and how to account for lipids or preservatives}

Lipid extraction and DMSO preservation had predictable effects on isotope ratios (Tables 2 to 4 ), suggesting that correction for lipid content or for immersion in preservative might be envisioned as an alternative to lipid extraction and DMSO extraction. This is assuming for DMSO that effects are constant over time. In turtle epidermis, a change in isotope ratios was documented over a $60 \mathrm{~d}$ immersion into DMSO and EDTA (Barrow et al. 2008). In our case, tis- sues were immersed in DMSO (no EDTA) for much longer (1 yr), specifically to ensure full penetration of DMSO and salt in tissue and equilibrium with the medium. We cannot rule out the possibility of longerterm effects of DMSO on isotopic values given that subsampling was not performed over the course of the experiment and beyond 1 yr of storage. However, based on studies on long-term preservation in ethanol or formalin, we suspect changes in isotope ratios after 1 yr storage to be insignificant (Edwards et al. 2002, Sarakinos et al. 2002, Syväranta et al. 2008, Carabel et al. 2009) and correction curves presented here to be valid beyond 1 yr storage. However, we caution against using these corrections for tissues other than skin, species other than cetaceans, or storage periods $<1 \mathrm{yr}$.

The proposed solution to the $\delta^{15} \mathrm{~N}$ biases induced by lipid extraction has been to analyze separate aliquots of samples for $\mathrm{C}$ and $\mathrm{N}$ isotopes (Sotiropoulos et al. 2004). The doubling of costs associated with this recommendation triggered multiple investigations of relationships between lipid content and $\mathrm{C}$ isotope ratios and circumstances when lipid correction of $\delta^{13} \mathrm{C}$ values or lipid extraction may be required (e.g. Sotiropoulos et al. 2004, Murry et al. 2006, Søreide et al. 2006, Logan et al. 2008). In general for animal species, the effects of lipid extraction $\left(\Delta \delta^{13} C\right)$ increase as tissue becomes depleted in ${ }^{13} \mathrm{C}$ (Bodin et al. 2007, the present study) or with lipid content (Tieszen \& Boutton 1989, Focken \& Becker 1998, Sweeting et al. 2006, Layman et al. 2007, Ricca et al. 2007, Smyntek et al. 2007, Mintenbeck et al. 2008). In turn, tissue lipid content is also positively correlated with $\mathrm{C}: \mathrm{N}$ ratio (McConnaughey \& McRoy 1979, Schmidt et al. 2003, Sweeting et al. 2006, Post et al. 2007, Smyntek et al. 2007, Logan et al. 2008, Mintenbeck et al. 2008). Lipidcorrection models often incorporate $\mathrm{C}: \mathrm{N}$ ratio as it can be readily derived from mass percentage of $\mathrm{C}$ and $\mathrm{N}$ during determination of isotope ratios. McConnaughey \& McRoy (1979) assumed a C:N ratio of 4.0 as normal for muscle or whole body of marine invertebrates and vertebrates, i.e. any tissue with $\mathrm{C}: \mathrm{N}<4.0$ required negative $\delta^{13} \mathrm{C}$ correction while anything $>4.0$ required positive correction. Their method resulted in corrections $<1 \%$ for fish and benthic invertebrates with $\mathrm{C}: \mathrm{N}$ ratios of 3.3 to 5.1. Depletions observed in the present study following lipid extraction for cetacean skin with $\mathrm{C}: \mathrm{N}$ ratios within this range were higher than those predicted by the M\&M model (1 to $>2 \%$; Fig. 4 ), suggesting that relatively large lipid effects occur even at low C:N ratios, at least for tissues such as skin. Other proposals, for instance, to not account for lipids when restricting analyses to a specific tissue, species, or ageclass (Sotiropoulos et al. 2004) or when C:N ratio is $<3.5$ (i.e. below $\sim 5 \%$ lipids for aquatic species) (Post et 
al. 2007) or when lipid content is $<15 \%$ (Ricca et al. 2007), are also not supported by our study (Fig. 2). Errors of the magnitude observed in our study when not accounting for lipids are equivalent to or greater than the $1 \%$ trophic increment in $\delta^{13} \mathrm{C}$ values observed for marine food webs (DeNiro \& Epstein 1978, Peterson \& Fry 1987, Caut et al. 2009) and so may introduce significant biases in interpretation of food-web structure and relative placement in the isotopic space (Murry et al. 2006). Circumstances where lipid content or lipid extraction have little effect on isotope signatures and our interpretation of trophic ecology or habitat use are exceptions rather than the norm, although the significance of biases depend on the study questions (Sotiropoulos et al. 2004, Post et al. 2007, Ricca et al. 2007). We therefore recommend extracting lipids or correcting for them systematically when interested in $\delta^{13} \mathrm{C}$ values unless their insignificance is unequivocally demonstrated for the tissue and species of interest.

\section{Lipid normalization biases and errors}

The usefulness of arithmetical correction of $\delta^{13} \mathrm{C}$ values for lipids largely depends on their precision and accuracy, and their reliability and robustness when applied to a variety of tissues or species. A preference is generally given to models with fewer assumptions, and using information easily acquirable. While the Post et al. (2007) and McConnaughey \& McRoy (1979) models were developed for muscle or whole body of a variety of aquatic vertebrates and invertebrates, the mass-balance approach of Fry et al. (2003) was a more general model, theoretically applicable to any tissue, although it was proposed in the context of a study on shrimp ecology. Similar to Logan et al. (2008), we conclude that, irrespective of its type, a model specific to a tissue and species of interest usually typically fits the data best. Our simple tissue- and species-specific linear model was the most precise and accurate of those tested in our study, as it resulted in no deviance (mean of residuals from predicted versus observed $=0$ ) and the lowest mean errors about the mean. This simple linear regression calculated lipid-free $\delta^{13} \mathrm{C}$ directly from the measured $\delta^{13} \mathrm{C}_{\text {bulk }}$ and therefore required no assumptions as to the value of other parameters. As a result, we recommend the use of this tissue- and species-specific model when dealing with 1 of the 3 cetacean species groups tested. However, when generalized to cetacean skin, this simple model provided results that were less accurate or precise than models developed for a wider range of species or tissues (Tables $2 \& 4$ ). For instance, the M\&M approach fitted to species-specific data performed better than the simple linear model generalized to cetacean skin for beluga and porpoises. In turn, the mass-balance model also performed remarkably well for skin and the 3 cetacean groups, and better compared to the M\&M model, regardless of the $D$ value used, as mean errors were $<0.2$ to $0.4 \%$ and maximum errors were, with 1 exception, $<0.5 \%$.

Despite these variations, all of the lipid-normalization models tested, with the exception of the one proposed by Post et al. (2007), might be considered reliable when applied to cetacean skin, as they resulted in errors no greater than when models were applied to other species or tissues. These performances were attained only when key parameters are either known or allowed to be re-estimated. Similar results were obtained with other species and tissues. For example, the M\&M model underestimated lipid-free $\delta^{13} \mathrm{C}$ values for a variety of tissues of aquatic fish or invertebrates (Kiljunen et al. 2006, Post et al. 2007, Smyntek et al. 2007). However, refitting the model to the data or using species- or tissue-specific parameters improved model fit for aquatic fish (Kiljunen et al. 2006, Logan et al. 2008). Similar conclusions were obtained with the mass-balance model when applied to most aquatic vertebrates and some zooplankton species while adjusting model parameters according to species and tissues (Sweeting et al. 2006, Smyntek et al. 2007, Logan et al. 2008; but see Mintenbeck et al. 2008). Mixed results were obtained with aquatic invertebrates, preventing generalization of lipid-normalization models to these species and promoting, for now, lipid extraction and separate analyses for $\mathrm{C}$ and $\mathrm{N}$ determination as the best way to account for lipids in these species (Kiljunen et al. 2006, Logan et al. 2008).

These results emphasize the sensitivity of models to parameter values. For instance, mass-balance correction is highly sensitive to $\mathrm{C}: \mathrm{N}_{\text {protein }}$ (Sweeting et al. 2006, Bodin et al. 2007); a change in this value from 3.2 to 3.5 doubled mean absolute errors in our study. The mass-balance model varied little with $D$ values of 6 to $7 \%$, but other studies documented notable effects on model results when varying this parameter over a wider range of values (Smyntek et al. 2007). The M\&M approach was sensitive to both $C: \mathrm{N}_{\text {protein }}$ and $D$ (Kiljunen et al. 2006, the present study). The M\&M approach also assumes a particular relationship between lipid content and $\mathrm{C}: \mathrm{N}_{\text {bulk }}$ that is similar for all marine vertebrates and invertebrates. In the present study, we used this relationship directly for estimating lipid content from $\mathrm{C}: \mathrm{N}_{\text {bulk }}$ as we did not measure sample lipid content. The relatively good performance of the M\&M approach supports previous observations that this equation is relatively accurate and might be used with a variety of species and tissues (Kiljunen et al. 2006) although developing species- and tissuespecific relationships from direct lipid measurement of a subsample is recommended. Most of the models also 
assume a non-linear relationship between the C:N ratio and lipid content and $\Delta \delta^{13} \mathrm{C}$ because of the expectation that $\Delta \delta^{13} \mathrm{C}$ will converge on $D$ at high values of C:N ratios (McConnaughey \& McRoy 1979). Although supportive of this theory, Post et al. (2007) instead determined that this relationship was linear, at least over the range of $\mathrm{C}: \mathrm{N}$ they measured (approximately 3 to 7 ) for 22 aquatic animals, and used this relationship to develop their lipid correction. Our data, particularly those of Balaenopteridae, which span a wider range of C:N ratios, support non-linearity of the relationship (Fig. 4). Values of $D$ for cetacean skin (6.2 to $6.7 \%$ ) were well within the range of those from a variety of aquatic species and tissues (McConnaughey \& McRoy 1979, Kiljunen et al. 2006, Smyntek et al. 2007, Logan et al. 2008). However, the slight underestimation of lipid-free $\delta^{13} \mathrm{C}$ values for beluga and porpoises when $D$ was $<7 \%$ suggest that $D$, which was obtained via the M\&M model, was probably closer to $7 \%$ for these 2 species (as denoted by a zero deviance for $D=7 \%$ ). Along the same lines, the near-zero deviance for a $D$ of $6.2 \%$ for Balaenopteridae and a $\mathrm{C}: \mathrm{N}$ ratio of 3.2 for pure protein of cetacean skin indicate that they were reasonable values.

The mass-balance model of Fry et al. (2003), which requires fewer assumptions and parameters, and is not limited by the span of values for $\mathrm{C}: \mathrm{N}_{\text {bulk }}$ for model fit (see Post et al. 2007), might be the most widely and easily applicable lipid-normalization model for aquatic species, as it performed reasonably well with a range of aquatic species and tissues (Sweeting et al. 2006, Smyntek et al. 2007, Logan et al. 2008; but see Mintenbeck et al. 2008), including cetacean skin in the present study. However, analysis of a subsample to determine $C: \mathrm{N}_{\text {protein }}$ is critical for model adequacy. We also recommend experimentally determining the $\delta^{13} \mathrm{C}$ offset of lipids relative to protein $D$ directly from samples, as its estimation using the M\&M approach might be somewhat inaccurate (see above).

The decision to lipid-normalize $\delta^{13} \mathrm{C}$ values, and thus to tolerate a certain amount of imprecision in results, over measuring $\delta^{13} \mathrm{C}$ from an aliquot of lipid-extracted samples largely depends on study objectives and expected results. Errors introduced in $\delta^{13} \mathrm{C}$ values by correction for lipid or preservative or in $\delta^{15} \mathrm{~N}$ values by lipid extraction may distort trophic structure and foodweb placement in the isotopic space, and so might limit comparisons among studies (Murry et al. 2006). The effects of errors associated with lipid normalization on isotopic mixing model outputs increase with the reduction of the isotopic distance between end members (Pinnegar \& Polunin 1999, Post et al. 2007, the present study). Although a trophic enrichment of 3 to $4 \%$ is expected in $\delta^{15} \mathrm{~N}$ (DeNiro \& Epstein 1981, Minagawa \& Wada 1984, Peterson \& Fry 1987, Post 2002, Caut et al.
2009) and differences of up to $15 \%$ exist between some C sources such as $\mathrm{C}_{3}$ and $\mathrm{C}_{4}$ plants (Kelly 2000, Fry 2006), food sources in many studies of the feeding ecology of marine species are often closer isotopically than these values. For instance, in the Estuary and Gulf of St. Lawrence, Canada, C sources between marine and estuarine regions and between benthic and pelagic systems differ in $\delta^{13} \mathrm{C}$ by 2 to $3.5 \%$ and 5 to $9 \%$, respectively (Lesage et al. 2001). Maximum differences in $\delta^{15} \mathrm{~N}$ values between major forage species in the estuary, i.e. euphausiids (Thysanoessa sp.), American sand lance Ammodytes sp. and capelan Mallotus villosus or Atlantic herring Clupea harengus, do not exceed $2.4 \%$. Using the mass-balance species- and tissue-specific lipid-normalization model (with mean and maximum errors of 0.26 and $0.47 \%$, respectively) with these values would result in biases of 10 to $22 \%$ in diet contributions. Using predicted DMSO-free $\delta^{15} \mathrm{~N}$ values would result in errors of up to $50 \%$ in prey contribution. Although errors introduced by lipid normalization or other processes are often minimized when similar to analytical errors from isotopic determination, they are cumulative as are the sum of 2 variances (Sokal \& Rohlf 1981), and can increase the overall bias in diet estimates (Stenroth et al. 2006). Consequently, we recommend lipid extraction of separate aliquots of samples for determination of $\delta^{13} \mathrm{C}$ and $\delta^{15} \mathrm{~N}$ values when maximum precision is needed for estimating diet composition. Our study provides a model for predicting the impact of errors anticipated from lipid correction or preservative extraction on mixing model results, which can be generalized to other tissues, species, or preservatives.

Acknowledgements. We thank A. Dallaire, S. Guittard, J. Higdon, J. Keays, S. Lair, L. Measures, I. Mikaelian, C. Nozères, R. Plante, the St. Lawrence National Institute of Ecotoxicology, and GREMM (Group of Research and Education on Marine Mammals) for sample collection. We thank A. Robillard for sample preparation, and W. Mark, M. E. Patton, and B. Drimmie from the Environmental Isotope Laboratory for running isotope analyses. We thank T. Doniol-Valcroze, $M$. Hammill, and C. Nozères for fruitful discussions and comments on the manuscript. This study was funded under the Environmental Science Strategic Research Fund, Species at Risk program and Nunavut Implementation Fund of Fisheries and Oceans Canada and by the Nunavut Wildlife Management Board.

\section{LITERATURE CITED}

Alexander SA, Hobson KA, Gratto-Trevor CL, Diamond AW (1996) Conventional and isotopic determinations of shorebird diets at an inland stopover: the importance of invertebrates and Potamogeton pectinatus tubers. Can J Zool 74: $1057-1068$

Amaral RS (2010) Use of alternative matrices to monitor steroid hormones in aquatic mammals: a review. Aquat Mamm 36:162-171 
Atwell L, Hobson KA, Welch HE (1998) Biomagnification and bioaccumulation of mercury in an arctic marine food web: insights from stable nitrogen isotope analysis. Can J Fish Aquat Sci 55:1114-1121

Barnes H, Blackstock J (1973) Estimation of lipids in marine animals and tissues: detailed investigation of the sulphophosphovanillin method for 'total' lipids. J Exp Mar Biol Ecol 12:103-118

Barrow LM, Bjorndal KA, Reich KJ (2008) Effects of preservation method on stable carbon and nitrogen isotope values. Physiol Biochem Zool 81:688-693

Bearhop S, Teece MA, Waldron S, Furness RW (2000) Influence of lipid and uric acid on $\delta^{13} \mathrm{C}$ and $\delta^{15} \mathrm{~N}$ values of avian blood: implications for trophic studies. Auk 117:504-507

Bischoff K, Lamm C, Erb HN, Hillebrandt JR (2008) The effects of formalin fixation and tissue embedding of bovine liver on copper, iron, and zinc analysis. J Vet Diagn Invest 20:220-224

Bodin N, Le Loc'h F, Hily C (2007) Effect of lipid removal on carbon and nitrogen stable isotope ratios in crustacean tissues. J Exp Mar Biol Ecol 341:168-175

Bonin W, Vladykov VD (1940) Étude sur les mammifères aquatiques. I. La peau du marsouin blanc ou beluga. Nat Can 67:253-287

Borobia M, Gearing PJ, Simard Y, Gearing JN, Béland P (1995) Blubber fatty acids of finback and humpback whales from the Gulf of St. Lawrence. Mar Biol 122: 341-353

Brown GW Jr (1976) Biochemical aspects of detoxification in the marine environment. In: Malins DC, Sargent JR (eds) Biochemical and biophysical perspectives in marine biology. Academic Press, London, p 319-406

Budge SM, Iverson SJ, Koopman HN (2006) Studying trophic ecology in marine ecosystems using fatty acids: a primer on analysis and interpretation. Mar Mamm Sci 22: 759-801

Bustamante P, Lahaye V, Durnez C, Churlaud C, Caurant F (2006) Total and organic Hg concentrations in cephalopods from the North Eastern Atlantic waters: influence of geographical origin and feeding ecology. Sci Total Environ 368:585-596

Carabel S, Verísimo P, Freire J (2009) Effects of preservatives on stable isotope analyses of four marine species. Estuar Coast Shelf Sci 82:348-350

Caut S, Angulo E, Courchamp F (2009) Variation in discrimination factors $\left(\Delta^{15} \mathrm{~N}\right.$ and $\left.\Delta^{13} \mathrm{C}\right)$ : the effect of diet isotopic values and applications for diet reconstruction. J Appl Ecol 46:443-453

Crawford K, McDonald RA, Bearhop S (2008) Applications of stable isotope techniques to the ecology of mammals. Mammal Rev 38:87-107

Das K, Beans C, Holsbeek L, Mauger G, Berrow SD, Rogan E, Bouquegneau JM (2003) Marine mammals from northeast Atlantic: relationship between their trophic status as determined by $\delta^{13} \mathrm{C}$ and $\delta^{15} \mathrm{~N}$ measurements and their trace metal concentrations. Mar Environ Res 56:349-365

Degens ET, Behrendt M, Gotthardt B, Reppmann E (1968) Metabolic fractionation of carbon isotopes in marine plankton. II. Data on samples collected off the coasts of Peru and Ecuador. Deep-Sea Res Oceanogr Abstr 15: $11-20$

> DeNiro MJ, Epstein S (1977) Mechanism of carbon isotope fractionation associated with lipid synthesis. Science 197: 261-263

> DeNiro MJ, Epstein S (1978) Influence of diet on the distribution of carbon isotopes in animals. Geochim Cosmochim Acta 42:495-506
DeNiro MJ, Epstein S (1981) Influence of diet on the distribution of nitrogen isotopes in animals. Geochim Cosmochim Acta 45:341-351

> Edwards MS, Turner TF, Sharp ZD (2002) Short- and longterm effects of fixation and preservation on stable isotope values $\left(\delta^{13} \mathrm{C}, \delta^{15} \mathrm{~N}, \delta^{34} \mathrm{~S}\right)$ of fluid-preserved museum specimens. Copeia 2002:1106-1112

Focken U, Becker K (1998) Metabolic fractionation of stable carbon isotopes: implications of different proximate compositions for studies of the aquatic food webs using $\delta^{13} \mathrm{C}$ data. Oecologia 115:337-343

Folch J, Lees M, Stanley GHS (1957) A simple method for the isolation and purification of total lipids from animal tissues. J Biol Chem 226:497-509

Fry B (2006) Stable isotope ecology. Springer, New York, NY $>$ Fry B, Baltz DM, Benfield MC, Fleeger JW, Gace A, Haas HL, Quiñones-Rivera ZJ (2003) Stable isotope indicators of movement and residency for brown shrimp (Farfantepenaeus aztecus) in coastal Lousiana marshscapes. Estuaries 26:82-97

Gearing JN (1991) The study of diet and trophic relationships through natural abundance ${ }^{13} \mathrm{C}$. In: Coleman DC, Fry B (eds) Carbon isotope techniques. Academic Press, Toronto, p 201-218

Geraci JR, Lounsbury VJ (1993) Marine mammals ashore. A field guide for strandings. Texas A\&M Sea Grant College Program, Galveston, TX

Giacometti L (1967) The skin of the whale (Balaenoptera physalus). Anat Rec 159:69-76

Gibbs RH Jr, Jarosewich E, Windom HL (1974) Heavy metal concentrations in museum fish specimens: effects of preservatives and time. Science 184:475-477

Goericke R, Fry B (1994) Variation of marine plankton $\delta^{13} \mathrm{C}$ with latitude, temperature, and dissolved $\mathrm{CO}_{2}$ in the world ocean. Global Biogeochem Cycles 8:85-90

> Gordeliy VI, Kiselev MA, Lesieur P, Pole AV, Teixeira J (1998) Lipid membrane structure and interactions in dimethyl sulfoxide/water mixtures. Biophys J 75:2343-2351

Haldiman JT, Tarpley RJ (1993) Anatomy and physiology. In: Burns JJ, Montague JJ, Cowles CJ (eds) The bowhead whale. Spec Publ 2. The Society for Marine Mammalogy, Lawrence, KS, p 71-156

Haldiman JT, Henk WG, Henry RW, Albert TF, Abdelbaki YZ, Duffield DW (1985) Epidermal and papillary dermal characteristics of the bowhead whale (Balaena mysticetus). Anat Rec 211:391-402

Hamanaka T (1981) Effects of formalin preservation on heavy metal concentration in zooplankton. Bull Fac Fish Hokkaido Univ 32:376-387

Harrison RJ, Thurley KW (1974) Structure of the epidermis in Tursiops, Delphinus, Orcinus and Phocoena. In: Harrison RJ (eds) Functional anatomy of marine mammals, Vol 2. Academic Press, London, p 45-71

- Hobson KA, Gibbs HL, Gloutney ML (1997) Preservation of blood and tissue samples for stable-carbon and stablenitrogen isotope analysis. Can J Zool 75:1720-1723

> Hobson KA, Fisk A, Karnovsky N, Holst M, Gagnon JM, Fortier M (2002) A stable isotope $\left(\delta^{13} \mathrm{C}, \delta^{15} \mathrm{~N}\right)$ model for the North Water food web: implications for evaluating trophodynamics and the flow of energy and contaminants. DeepSea Res II 49:5131-5150

Jacob SW, Herschler R (eds) (1975) Biological actions of dimethyl sulfoxide. Ann NY Acad Sci, Vol 243, New York

Jones FM, Pfeiffer CJ (1994) Morphometric comparison of the epidermis in several cetacean species. Aquat Mamm 20: $29-34$ 
Kelly JF (2000) Stable isotopes of carbon and nitrogen in the study of avian and mammalian trophic ecology. Can J Zool 78:1-27

Kiljunen M, Grey J, Sinisalo T, Harrod C, Immonen H, Jones RI (2006) A revised model for lipid-normalizing $\delta^{13} \mathrm{C}$ values from aquatic organisms, with implications for isotope mixing models. J Appl Ecol 43:1213-1222

Krahn MM, Herman DP, Matkin CO, Durban JW and others (2007) Use of chemical tracers in assessing the diet and foraging regions of eastern North Pacific killer whales. Mar Environ Res 63:91-114

Kurle CM, Worthy GAJ (2002) Stable nitrogen and carbon isotope ratios in multiple tissues of the northern fur seal Callorhinus ursinus: implications for dietary and migratory reconstructions. Mar Ecol Prog Ser 236:289-300

Layman CA, Arrington DA, Montaña CG, Post DM (2007) Can stable isotope ratios provide for community-wide measures of trophic structure? Ecology 88:42-48

Lesage V, Hammill MO, Kovacs KM (2001) Marine mammals and the community structure of the Estuary and Gulf of St Lawrence, Canada: evidence from stable isotope analysis. Mar Ecol Prog Ser 210:203-221

Ling JK (1974) The integument of marine mammals. In: Harrison RJ (eds) Functional anatomy of marine mammals, Vol 2. Academic Press, London, p 1-44

Logan JM, Lutcavage ME (2008) A comparison of carbon and nitrogen stable isotope ratios of fish tissues following lipid extractions with non-polar and traditional chloroform/ methanol solvent systems. Rapid Commun Mass Spectrom 22:1081-1086

Logan JM, Jardine TD, Miller TJ, Bunn SE, Cunjak RA, Lutcavage ME (2008) Lipid corrections in carbon and nitrogen stable isotope analyses: comparison of chemical extraction and modelling methods. J Anim Ecol 77: 838-846

Mayer DG, Butler DG (1993) Statistical validation. Ecol Modell 68:21-32

McConnaughey T (1978) Ecosystems naturally labeled with carbon-13: applications to the study of consumer food webs. MSc thesis, University of Alaska, Fairbanks, AK

> McConnaughey T, McRoy CP (1979) Food-web structure and the fractionation of carbon isotopes in the Bering Sea. Mar Biol 53:257-262

Minagawa M, Wada E (1984) Stepwise enrichment of ${ }^{15} \mathrm{~N}$ along food chains: further evidence and the relation between $\delta^{15} \mathrm{~N}$ and animal age. Geochim Cosmochim Acta 48:1135-1140

> Mintenbeck K, Brey T, Jacob U, Knust R, Struck U (2008) How to account for the lipid effect on carbon stable-isotope ratio $\left(\delta^{13} \mathrm{C}\right)$ : sample treatment effects and model bias. J Fish Biol 72:815-830

Murry BA, Farrell JM, Teece MA, Smyntek PM (2006) Effect of lipid extraction on the interpretation of fish community trophic relationships determined by stable carbon and nitrogen isotopes. Can J Fish Aquat Sci 63:2167-2172

> Nriagu JO, Lawson G, Wong HKT, Azcue JM (1993) A protocol for minimizing contamination in the analysis of trace metals in Great Lakes waters. J Gt Lakes Res 19: 175-182

Outridge PM, Evans RD, Wagemann R, Stewart REA (1997) Historical trends of heavy metals and stable lead isotopes in beluga (Delphinapterus leucas) and walrus (Odobenus rosmarus rosmarus) in the Canadian Arctic. Sci Total Environ 203:209-219

Painter S, Cameron EM, Allan R, Rouse J (1994) Reconnaissance geochemistry and its environmental relevance. J Geochem Explor 51:213-246
Parnell AC, Inger R, Bearhop S, Jackson AL (2010) Source partitioning using stable isotopes: coping with too much variation. PLoS ONE 5:e9672

Parsons KM, Durban JW, Claridge DE (2003) Comparing two alternative methods for sampling small cetaceans for molecular analysis. Mar Mamm Sci 19:224-231

> Peterson BJ, Fry B (1987) Stable isotopes in ecosystem studies. Annu Rev Ecol Syst 18:293-320

Phillips DL, Gregg JW (2003) Source partitioning using stable isotopes: coping with too many sources. Oecologia 136: 261-269

Pinnegar JK, Polunin NVC (1999) Differential fractionation of $\delta^{13} \mathrm{C}$ and $\delta^{15} \mathrm{~N}$ among fish tissues: implication for the study of trophic interactions. Funct Ecol 13:225-231

> Post DM (2002) Using stable isotopes to estimate trophic position: models, methods, and assumptions. Ecology 83: 703-718

Post DM, Layman CA, Arrington DA, Takimoto G, Quattrochi J, Montaña CG (2007) Getting to the fat of the matter: models, methods, and assumptions for dealing with lipids in stable isotope analyses. Oecologia 152:179-189

R Development Core Team (2009) R: a language and environment for statistical computing. R Foundation for Statistical Computing, Vienna

> Renaud CB, Nriagu JO, Wong HKT (1995) Trace metals in fluid-preserved museum fish specimens. Sci Total Environ 159:1-7

Ricca MA, Miles AK, Anthony RG, Deng X, Hung SSO (2007) Effect of lipid extraction on analyses of stable carbon and stable nitrogen isotopes in coastal organisms of the Aleutian archipelago. Can J Zool 85:40-48

> Sarakinos HC, Johnson ML, Vander Zanden MJ (2002) A synthesis of tissue-preservation effects on carbon and nitrogen stable isotope signatures. Can J Zool 80:381-387

SAS Institute (1990) SAS/STAT users guide, 4th edn. SAS Institute, Cary, NC

- Satterfield FRI, Finney BP (2002) Stable isotope analysis of Pacific salmon: insight into trophic status and oceanographic conditions over the last 30 years. Prog Oceanogr 53:231-246

Schell DM (2000) Declining carrying capacity in the Bering Sea: isotopic evidence from whale baleen. Limnol Oceanogr 45:459-462

Schlechtriem C, Focken U, Becker K (2003) Effect of different lipid extraction methods on $\delta^{13} \mathrm{C}$ of lipid and lipid-free fractions of fish and different fish feeds. Isotopes Environ Health Stud 39:135-140

Schmidt K, Atkinson A, Stubing D, McClelland JW, Montoya JP, Voss M (2003) Trophic relationships among Southern Ocean copepods and krill: some uses and limitations of a stable isotope approach. Limnol Oceanogr 48:277-289

Semmens BX, Moore JW, Ward EJ (2009) Improving Bayesian isotope mixing models: a response to Jackson et al. (2009). Ecol Lett 12:E6-E8

> Smetacek V, Nicol S (2005) Polar ocean ecosystems in a changing world. Nature 437:362-368

Smyntek PM, Teece MA, Schulz KL, Thackeray SJ (2007) A standard protocol for stable isotope analysis of zooplankton in aquatic food web research using mass balance correction models. Limnol Oceanogr 52:2135-2146

Sokal RR, Rohlf FJ (1981) Biometry. WH Freeman, New York, NY

Sokolov W (1960) Some similarities and dissimilarities in the structure of the skin among the members of the suborders Odonceti and Mystacoceti (Cetacea). Nature 185:745-747

Sokolov VE (1982) Mammal skin. University of California Press, London 
Søreide JE, Tamelander T, Hop H, Hobson KA, Johansen I (2006) Sample preparation effects on stable C and N isotope values: a comparison of methods in Arctic marine food web studies. Mar Ecol Prog Ser 328:17-28

Sotiropoulos MA, Tonn WM, Wassenaar LI (2004) Effects of lipid extraction on stable carbon and nitrogen isotope analyses on fish tissue: potential consequences for food web studies. Ecol Freshwat Fish 13:155-160

Stenroth P, Holmqvist N, Nyström P, Berglund O, Larsson P, Granéli W (2006) Stable isotopes as an indicator of diet in omnivorous crayfish (Pacifastacus leniusculus): the influence of tissue, sample treatment, and season. Can J Fish Aquat Sci 63:821-831

Sweeting CJ, Polunin NVC, Jennings S (2004) Tissue and fixative dependent shifts of $\delta^{13} \mathrm{C}$ and $\delta^{15} \mathrm{~N}$ in preserved ecological material. Rapid Commun Mass Spectrom 18: $2587-2592$

Sweeting CJ, Polunin NVC, Jennings S (2006) Effects of chemical lipid extraction and arithmetic lipid correction on stable isotope ratios of fish tissues. Rapid Commun Mass Spectrom 20:595-601

Editorial responsibility: Hans Heinrich Janssen, Oldendorf/Luhe, Germany
Syväranta J, Vesala S, Rask M, Ruuhijärvi J, Jones RI (2008) Evaluating the utility of stable isotope analyses of archived freshwater sample materials. Hydrobiologia 600:121-130

Szmant HH (1975) Physical properties of dimethyl sulfoxide and its function in biological systems. Ann NY Acad Sci Vol 243, p 20-23

Tieszen LL, Boutton TW (1989) Stable carbon isotopes in terrestrial ecosystem research. In: Rundel PW, Ehleringer JR, Nagy KA (eds) Stable isotopes in ecological research. Springer-Verlag, New York, NY, p 167-195

Todd S, Ostrom P, Lien J, Abrajano J (1997) Use of biopsy samples of humpback whale (Megaptera novaeangliae) skin for stable isotope $\left(\delta^{13} \mathrm{C}\right)$ determination. J Northwest Atl Fish Sci 22:71-76

Vitousek PM, Aber JD, Howarth RW, Likens GE and others (1997) Human alteration of the global nitrogen cycle: sources and consequences. Ecol Appl 7:737-750

> Wanek W, Heintel S, Richter A (2001) Preparation of starch and other carbon fractions from higher plant leaves for stable carbon isotope analysis. Rapid Commun Mass Spectrom 15:1136-1140

Submitted: July 6, 2010; Accepted: September 13, 2010 Proofs received from author(s): November 17, 2010 